\title{
Performance of Photovoltaic Modules of Different Solar Cells
}

\author{
Ankita Gaur and G. N. Tiwari \\ Center for Energy Studies, Indian Institute of Technology Delhi, Hauz Khas, New Delhi 110016, India \\ Correspondence should be addressed to Ankita Gaur; ankitaph08@gmail.com
}

Received 6 May 2013; Revised 24 July 2013; Accepted 29 July 2013

Academic Editor: Guillaume Zoppi

Copyright (C) 2013 A. Gaur and G. N. Tiwari. This is an open access article distributed under the Creative Commons Attribution License, which permits unrestricted use, distribution, and reproduction in any medium, provided the original work is properly cited.

\begin{abstract}
In this paper, an attempt of performance evaluation of semitransparent and opaque photovoltaic (PV) modules of different generation solar cells, having the maximum efficiencies reported in the literature at standard test conditions (STC), has been carried out particularly for the months of January and June. The outdoor performance is also evaluated for the commercially available semitransparent and opaque PV modules. Annual electrical energy, capitalized cost, annualized uniform cost (unacost), and cost per unit electrical energy for both types of solar modules, namely, semitransparent and opaque have also been computed along with their characteristics curves. Semitransparent PV modules have shown higher efficiencies compared to the opaque ones. Calculations show that for the PV modules made in laboratory, CdTe exhibits the maximum annual electrical energy generation resulting into minimum cost per unit electrical energy, whereas a-Si/nc-Si possesses the maximum annual electrical energy generation giving minimum cost per unit electrical energy when commercially available solar modules are concerned. CIGS has shown the lowest capitalized cost over all other PV technologies.
\end{abstract}

\section{Introduction}

According to the Annual Energy Review of US Energy Information Administration (EIA) in 2011, industrial, residential and commercial, transportation, and electric power generation are the primary sectors of energy consumption that account for, respectively, $\sim 21 \%, 11 \%, 28 \%$, and $40 \%$ of the total consumption. Petroleum (37\%), natural gas (26\%), coal $(20 \%)$, renewable energy (9\%), and nuclear electric power $(8 \%)$ are the main sources being utilized to run the energy consumption sectors. The large percentage of energy is driven from the fossil fuels. In 2011, the US energy consumption accounted for $\sim 2.84 \times 10^{13} \mathrm{kWh}$, whereas the production was just only $\sim 2.28 \times 10^{13} \mathrm{kWh}$. And as per the Annual report of European Commission on Energy 2011, transport, industry, household, services, and agriculture account for, respectively, $32 \%, 25 \%, 27 \%, 14 \%$, and $2 \%$ of total energy consumption. Petroleum accounts $35.1 \%$, solid fuels account for, and $15.9 \%$, renewable account for, $9.8 \%$, nuclear power and natural gases account for, respectively, the $13.5 \%$ and $25.1 \%$ for fulfillment of the total energy requirement. Compared to 2009, the gross consumption increased by $3.3 \%$ in 2010 . In the context of present energy crisis in terms of demand and supply and the bad consequences of fossil fuels on our delicate environment, the development and use of renewable sources of energy has become very important.

Solar photovoltaic (PV) technology is one of the most important renewable sources of energy generation. Since the early realization of PV effect in 1839, there have been steady improvements in the performance of solar cells and the application of advanced materials has given birth to new generations of solar cells. Crystalline silicon (c-Si) was the first material giving practical solar cell [1]; therefore, the solar cells, based on c-Si are known as first generation solar cells. From the cost, performance, and processibility points of view, the application of new advanced materials gave birth to new generations of solar cells. The second and third generation PV cells were based on the thin film materials such as amorphous silicon (a-Si), cadmium telluride (CdTe), copper indium gallium diselenide (CIGS), organic semiconductors and organic dyes. Thin film materials are deposited either in single-junction or multijunction configurations referred to as stacked junction or tandem cells. A brief overview of different solar cells with their latest laboratory efficiencies is given in Table 1. The values have been taken from the website of National Renewable Energy Laboratory (NREL), USA [2]. 
TABLE 1: Latest efficiencies of different solar cells $[2,3]$.

\begin{tabular}{lc}
\hline Solar cell materials & $\begin{array}{c}\text { Efficiency } \eta_{0}(\%) \\
\text { (Source: NREL, USA) }\end{array}$ \\
\hline Mono c-Si & 25.0 \\
Poly c-Si & 20.4 \\
\hline a-Si & 10.1 \\
a-Si/nc-Si & 12.3 \\
CdTe & 18.3 \\
CIGS & 20.3 \\
\hline Organic semiconductors & 10.7 \\
Organic dyes & 11.0 \\
\hline
\end{tabular}

PV modules have got various applications for electricity generation in remote, rural, and even in urban areas. They have got applications in different sectors ranging from agriculture, household to industry. PV modules can be used in most of the sectors where energy is required. The PV modules can be integrated in buildings to fulfill dual purposes, namely, generation of electricity and harvesting of thermal energy too. Such systems are known as building-integrated photovoltaic thermal (BIPVT) systems. BIPVT systems have got tremendous household and industry applications $[4,5]$. The demand of solar PV devices is increasing very fast, and as per the US-EIA report, the US photovoltaic industry hit a record in 2009 by shipping $\sim 1.3 \mathrm{GWp}$ solar cells and solar modules, that is, $\sim 30 \%$ more than that in 2008 . Out of that $\sim 0.58 \mathrm{GWp}$ was accounted by mono c-Si, $\sim 0.4 \mathrm{GWp}$ by poly $\mathrm{c}-\mathrm{Si}$, and $\sim 0.27$ was accounted by thin films (a-Si, nc-Si, $\mathrm{CdTe}$, and CIGS) solar cells. From the beginning, the PV modules based on c-Si have continued to dominate the PV market. Application of PV modules can fulfill our long-term energy demand, but they have got some implications too. High cost, cumbersome processing and difficulty in handling are some of the main implications in the present commercial $\mathrm{PV}$ technologies. Research is being done to make them more viable and more cost effective. In view of the increasing demand, the understanding of their performance in different environmental conditions becomes of high importance. An analysis of the outdoor performance of PV modules made of different generation solar cells is presented. The PV modules have been considered in the two well-known configurations, for example, semitransparent and opaque as shown in Figure 1, where the PV modules are prepared, respectively, on the glass and tedlar plates. For the PV modules made of $\mathrm{c}-\mathrm{Si}$ and poly c-Si solar cells, the top encapsulating covered plate is considered to be made of highly transparent glass, whereas the thin films PV modules are considered to be encapsulated by an EVA encapsulant only.

For incidence of the maximum solar radiation, the PV modules in northern hemisphere are placed south oriented, having inclination for horizontal surface equal to the latitude of the system's station [6-8]. The performance analysis of PV modules for the cold (January) and hot (June) climatic conditions of 2012 of New Delhi has been presented. New Delhi is located at $28.38 \mathrm{~N}, 77.12 \mathrm{E}$ in India; therefore, all the modules are considered to be south oriented and inclined at an angle of $30^{\circ}$ to the horizontal (see Figure 1). The analytical expressions for the electrical efficiency and temperatures of thin film PV modules have been derived. The performance of PV modules made of the solar cells with maximum laboratory efficiency is compared with that of those available in the market. The annual electrical energy and unit electrical generation of different PV modules have been computed by considering the following weather conditions for New Delhi [9].
(a) Clear days (blue sky),
(b) Hazy days (fully),
(c) Hazy and cloudy days (partially),
(d) Cloudy Days (fully).

\section{Modeling}

The efficiencies and temperature of PV module are calculated using energy balance equations. To write the energy balance equations for PV modules, the following assumptions have been considered:

(i) One-dimensional heat conduction,

(ii) the encapsulant ethylene vinyl acetate (EVA) is purely transparent,

(iii) the ohmic losses in solar cells and PV modules are negligible.

\subsection{Energy Balance Equations}

2.1.1. For Semitransparent Mono c-Si and Polyc-Si PV Modules. The energy balance equation for the semitransparent mono $c-$ Si or poly c-Si PV modules can be written as $[10,11]$

$\alpha_{c} \tau_{g} \beta_{c} I(t)=U_{T}\left(T_{c}-T_{a}\right)+U_{b}\left(T_{c}-T_{a}\right)+\eta_{c} \tau_{g} \beta_{c} I(t)$

[Rate of absorbed solar radiation received by solar cells]

$=[$ Rate of thermal energy loss from solar cells to ambient through top glass surface]

+ [Rate of thermal energy loss from solar cells to ambient through back glass surface]

$+[$ Rate of electrical energy generated from solar cells of PV module].

Here $U_{T}$ and $U_{b}$ can be defined as

$$
\begin{aligned}
& U_{T}=\left[\frac{L_{g}}{K_{g}}+\frac{1}{h_{0}}\right]^{-1}, \\
& U_{b}=\left[\frac{L_{g}}{K_{g}}+\frac{1}{h_{i}}\right]^{-1} .
\end{aligned}
$$

From (1), the cell temperature can be expressed as

$$
T_{c}=\frac{T_{a} U_{L}+\left(\alpha_{c} \tau_{g} \beta_{c}-\eta_{c} \beta_{c} \tau_{g}\right) I(t)}{U_{L}},
$$




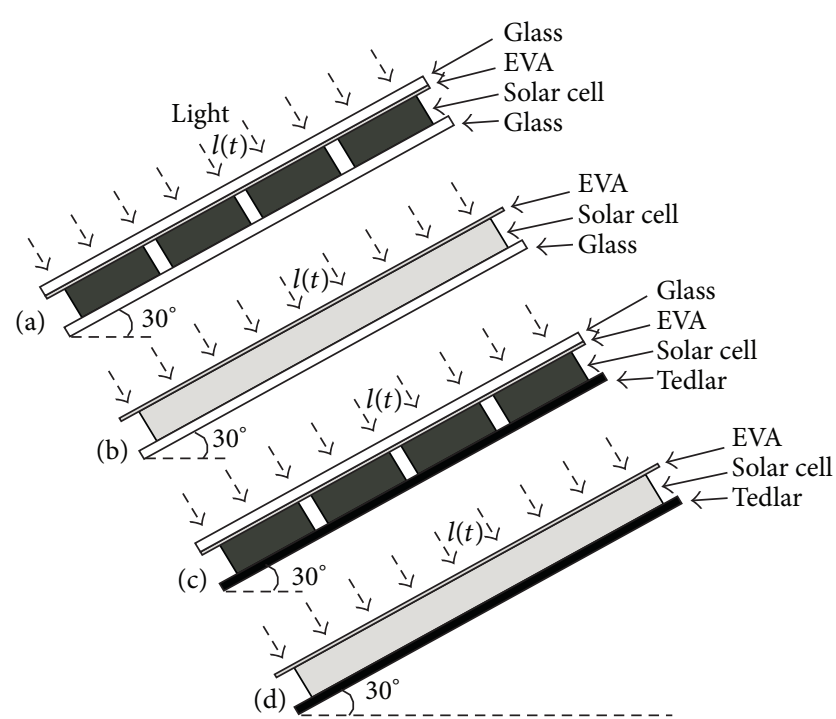

FIGURE 1: Schematic representation of (a) semitransparent c-Si, poly c-Si, (b) semitransparent thin films, (c) opaque c-Si, poly-Si, and (d) opaque thin films PV modules, inclined at an angle of $30^{\circ}$ from horizontal.

or

$$
T_{c}-T_{0}=T_{a}-T_{0}+\frac{\left(\alpha_{c} \tau_{g} \beta_{c}-\eta_{c} \beta_{c} \tau_{g}\right) I(t)}{U_{L}}
$$

where $U_{L}=U_{T}+U_{b}$. According to Evan $[12,13]$, the temperature dependence of the cell efficiency can be written as

$$
\eta_{c}=\eta_{0}\left[1-\beta_{0}\left(T_{c}-T_{0}\right)\right]
$$

With the help of (4) and (5), one can get the electrical efficiency of the cell as

$$
\eta_{c}=\frac{\eta_{0}\left[1-\beta_{0}\left\{\left(T_{a}-T_{0}\right)+\left(\tau_{g} \alpha_{c} \beta_{c} / U_{L}\right) I(t)\right\}\right]}{\left[1-\left(\eta_{0} \beta_{0} \tau_{g} \beta_{c} / U_{L}\right) I(t)\right]},
$$

and the module efficiency as

$$
\eta_{m}=\frac{P_{o}}{P_{\text {in }}}=\frac{\eta_{c} \beta_{c} \tau_{g} I(t)}{I(t)}
$$

or

$$
\eta_{m}=\eta_{c} \beta_{c} \tau_{g}
$$

2.1.2. For Opaque Mono c-Si and Poly c-Si PV Modules. The energy balance equation for the opaque mono $c-S i$ or poly cSi PV modules can be written as $[10,11]$

$$
\begin{aligned}
\tau_{g} & {\left[\alpha_{c} \beta_{c} I(t)+\left(1-\beta_{c}\right) \alpha_{T} I(t)\right] } \\
& =U_{T}\left(T_{c}-T_{a}\right)+U_{b}\left(T_{c}-T_{a}\right)+\tau_{g} \eta_{c} \beta_{c} I(t)
\end{aligned}
$$

[Rate of absorbed solar radiation received by solar cells]

$=[$ Rate of thermal energy loss from solar cells to ambient through top glass surface]

$+[$ Rate of thermal energy loss from solar cells to ambient through back glass surface]

$+[$ Rate of electrical energy generated from the solar cells of PV module].

From (9), the cell temperature can be written as

$$
T_{c}=\frac{\left[\tau_{g}\left\{\alpha_{c} \beta_{c}+\left(1-\beta_{c}\right) \alpha_{T}-\eta_{c} \beta_{c}\right\}\right] I(t)+U_{L} T_{a}}{U_{L}}
$$

or

$$
T_{c}-T_{0}=T_{a}-T_{0}+\frac{\left[\tau_{g}\left\{\alpha_{c} \beta_{c}+\left(1-\beta_{c}\right) \alpha_{T}-\eta_{c} \beta_{c}\right\}\right] I(t)}{U_{L}},
$$

where $U_{L}=U_{T}+U_{b}$. Therefore, now from (5) and (11) one gets

$$
\eta_{c}=\frac{\eta_{0}\left[1-\beta_{0}\left\{\left(T_{a}-T_{0}\right)+\left(\left\{\tau_{g} \alpha_{c} \beta_{c}+\left(1-\beta_{c}\right) \alpha_{T}\right\} / U_{L}\right) I(t)\right\}\right]}{\left[1-\left(\eta_{0} \beta_{0} \tau_{g} \beta_{c} / U_{L}\right) I(t)\right]}
$$

and the module efficiency

$$
\eta_{m}=\eta_{c} \beta_{c} \tau_{g}
$$

2.1.3. For Thin Film PV Modules. For a thin film PV module, the energy balance equation can be written as

$$
\begin{aligned}
& \alpha_{c}\left(1-R_{E}\right) I(t) \\
& \quad=h_{0}\left(T_{c}-T_{a}\right)+U_{b}\left(T_{c}-T_{a}\right)+\eta_{c}\left(1-R_{E}\right) I(t)
\end{aligned}
$$

[Rate of absorbed solar radiation received by solar cells]

$=[$ Rate of thermal energy loss from solar cells to ambient through top surface]

$+[$ Rate of thermal energy loss from solar cells to ambient through back surface of glass/tedlar]

$+[$ Rate of electrical energy generated by the solar cells of PV module].

For semitransparent PV module, $U_{b}$ is written as $U_{b}=$ $\left[L_{g} / K_{g}+1 / h_{i}\right]^{-1}$ (effective $\tau>0$ ) whereas for the opaque 
PV modules, $U_{b}$ is given by $U_{b}=\left[L_{T} / K_{T}+1 / h_{i}\right]^{-1}$ (effective $\tau=0)$. Now from (14), $T_{c}$ can be written as

$$
T_{c}=T_{a}+\frac{\alpha_{c}\left(1-R_{E}\right) I(t)-\eta_{c}\left(1-R_{E}\right) I(t)}{U_{L}}
$$

or

$$
T_{c}-T_{0}=\left(T_{a}-T_{0}\right)+\frac{\alpha_{c}\left(1-R_{E}\right) I(t)-\eta_{c}\left(1-R_{E}\right) I(t)}{U_{L}},
$$

where $U_{L}=h_{0}+U_{b}$. Now from (5) and (16) the cell efficiency can be given by

$$
\eta_{c}=\frac{\eta_{0}\left[1-\beta_{0}\left\{\left(T_{a}-T_{0}\right)+\left(\alpha_{c}\left(1-R_{E}\right) / U_{L}\right) I(t)\right\}\right]}{\left[1-\left(\eta_{0} \beta_{0}\left(1-R_{E}\right) / U_{L}\right) I(t)\right]},
$$

and the module efficiency will now be given by

$$
\eta_{m}=\eta_{c}\left(1-R_{E}\right) \text {. }
$$

2.2. Annual Electrical Energy. The hourly electrical energy of a PV module can be given by $E_{\text {el,hourly }}=\eta_{m} \times A_{m} \times I(t)$ [12]. And the daily electrical energy in KWh is obtained by $E_{\text {el,daily }}=\sum_{i=1}^{N_{1}}\left(E_{\text {el,hourly }, i} / 1000\right)$, where $N_{1}$ is the number of sun shine hours per day. The monthly electrical energy for the clear days (condition (a)) in KWh is calculated by the following expression:

$$
E_{\text {el,monthly }}=E_{\text {el,daily }} \times n_{1} \text {, }
$$

where $n_{1}$ is the number of clear days in a month. Now the annual electrical energy is calculated by

$$
E_{\mathrm{el}, \mathrm{annual}}=\sum_{i=1}^{12} E_{\mathrm{el}, \mathrm{monthly}, k}
$$

2.3. Cost Analysis. The capitalized cost $(K)$ is defined on the equivalent present value $\left(P_{n}\right)$ of the system lasting for $n$ years. The present value of the system based on an infinite time period can be represented as shown in Figure 12.

For a system costing $P_{n}$ and having service lifetime of $n$ years, the present value replacing out to infinity is given by $[7,10]$

$$
K=P_{n} F_{P K, i, n}
$$

where $K$ is the capitalized cost and $F_{P K, i, n}=(1+i)^{n} /(1+i)^{n}-$ 1 is the capitalized cost factor. $P_{n}$ can be calculated from

$$
\begin{aligned}
P_{n}= & \text { Total Initial Cost of module }(P) \\
& + \text { Operational and maintenance cost }(\mathrm{OM}) \\
& \times \text { Unacost present value factor }\left(F_{\mathrm{rp}, i, n}\right) \\
& - \text { Salvage value } \times \text { Present value factor }\left(F_{\mathrm{sp}, I, n}\right),
\end{aligned}
$$

where,

$$
\begin{gathered}
F_{R P, i, n}=\left[\frac{(1+i)^{n}-1}{i(1+i)^{n}}\right], \\
F_{S P, i, n}=(1+i)^{-n} .
\end{gathered}
$$

The annualized uniform cost (Unacost, $R$ ) and capitalized cost $(K)$ are related as $[7,10]$;

$$
R=i \cdot K
$$

Annualized uniform cost

$$
=\text { Worth of money } \times \text { Capitalised cost. }
$$

The cost for per unit electric energy production by a PV module is evaluated by

Unit electrical energy generation cost

$$
=\frac{\text { Unacost }}{\text { Annual Electrical Energy }} \text {. }
$$

\section{Methodology}

The climatic data for the solar radiation $I(t)$ on horizontal surface, ambient temperature $\left(T_{a}\right)$, and the number of days for the weather conditions (a), (b), (c), and (d) for Delhi was obtained from the Indian Metrological Department (IMD), Delhi. The following methodology has been used to evaluate the electrical efficiencies, annual electrical energy, and cost per unit electrical energy for the PV modules.

Step 1. The hourly solar radiation on the PV modules, at the $30^{\circ}$ inclination from the horizontal, was calculated using the Liu and Jordan method [14].

Step 2. The designed parameters, for both laboratory made and commercially available PV modules, used for calculations have been tabulated in Table 2. The corresponding references for the values of different parameters have been given in the table, and the values of rest of the parameters have been taken from [11].

Step 3. For the known climatic conditions and designed parameters, the cell temperatures and electrical efficiencies of the PV modules have been evaluated using the modeling given above. Note. The expressions of cell and module efficiencies are valid only for the condition $T_{c}-T_{0}>298 \mathrm{~K}$.

Step 4. The temperature of PV modules has been considered to be equal to that of the solar cells and calculated by the modeling above.

Step 5. The monthly electrical energy for clear days (condition (a)) has been evaluated using (19), and the same process was adopted to calculate the monthly electrical energy for other climatic conditions (b), (c), and (d). The total electrical energy for each month was obtained by adding the energy generations in the climatic conditions (a), (b), (c), and (d) in that month. 
TABLE 2: Design parameters of opaque and semitransparent PV modules.

\begin{tabular}{|c|c|c|c|c|c|c|c|}
\hline Parameters & $\mathrm{c}-\mathrm{Si}$ & Poly-Si & $\mathrm{a}-\mathrm{Si}$ & $\mathrm{CdTe}$ & CIGS & $\mathrm{a}-\mathrm{Si} / \mathrm{nc}-\mathrm{Si}$ & OPV \\
\hline \multicolumn{8}{|l|}{$A_{m}\left(\mathrm{~m}^{2}\right)$} \\
\hline Com. & 0.646 & 0.598 & 1.17 & 0.72 & 0.72 & 1.054 & - \\
\hline Lab. & 0.25 & 0.3006 & 0.29 & 0.325 & 0.507 & 0.401 & 0.487 \\
\hline$\alpha_{c}$ & 0.9 & 0.9 & 0.85 & 0.8 & 0.8 & 0.8 & 0.6 \\
\hline$\beta_{c}$ & 0.89 & 0.89 & 1 & 1 & 1 & 1 & 1 \\
\hline$\beta_{0}$ & $\begin{array}{c}0.0062 \\
{[15]}\end{array}$ & $\begin{array}{c}0.0049 \\
{[16]}\end{array}$ & $\begin{array}{c}0.001 \\
{[15]}\end{array}$ & $\begin{array}{c}0.002 \\
{[16]}\end{array}$ & $\begin{array}{c}0.0031 \\
{[15]}\end{array}$ & $\begin{array}{c}0.0023 \\
{[17]}\end{array}$ & $\begin{array}{c}0.002 \\
\text { [calculated] }\end{array}$ \\
\hline$\eta_{m 0}(\%)$ Com. & $\begin{array}{l}14.2 \\
{[18]}\end{array}$ & $\begin{array}{c}12.53 \\
{[18]}\end{array}$ & $\begin{array}{c}6.4 \\
{[19]}\end{array}$ & $\begin{array}{l}10.4 \\
{[20]}\end{array}$ & $\begin{array}{c}10.42 \\
{[21]}\end{array}$ & $\begin{array}{c}8.5 \\
{[22]}\end{array}$ & - \\
\hline$\alpha_{T}$ & 0.5 & & & & & & \\
\hline$\tau_{g}$ & 0.95 & & & & & & \\
\hline$h_{0}\left(\mathrm{~W} / \mathrm{m}^{2} \mathrm{~K}\right)$ & $\begin{array}{l}5.7+3 \\
v=0.5\end{array}$ & & & & & & \\
\hline$h_{i}\left(\mathrm{~W} / \mathrm{m}^{2} \mathrm{~K}\right)$ & $\begin{array}{l}2.8+3 \\
v=0.2\end{array}$ & & & & & & \\
\hline$L_{g}(\mathrm{~m})$ & 0.003 & & & & & & \\
\hline$K_{g}(\mathrm{~W} / \mathrm{m} \mathrm{K})$ & 1.1 & & & & & & \\
\hline$L_{T}(\mathrm{~m})$ & 0.000 & & & & & & \\
\hline$K_{T}(\mathrm{~W} / \mathrm{m} \mathrm{K})$ & 0.033 & & & & & & \\
\hline
\end{tabular}

Step 6. The Annual electrical energy was calculated using (20).

Step 7. $P_{n}$ has been calculated by (22). Operational and maintenance costs have been considered to be $10 \%$ whereas salvage value has been taken $5 \%$ of the initial cost $(P)$ of the modules.

Step 8. While calculating the electrical energy, the degradation rates per year of individual systems (Table 4) were also taken into account [23].

Step 9. The annualized capitalized cost $(K)$ has been calculated using (21).

Step 10. The unacost $(R)$ has been calculated using (24).

Step 11. Finally, the cost per unit electrical energy was calculated using (25). For the calculations of $K$ and $R$, interest rate has been considered to be $8 \%$.

Note. The values of different parameters given in Table 2 have been taken from the websites of different world known institutions/companies. First Solar is the world leading company of USA. in thin film PV module manufacturing. It is world's leading provider of solar energy solutions. First Solar holds the world record in CdTe module and cell efficiencies and owns mega solar projects in the world. Global Solar, USA, is a leading manufacturer of flexible solar technologies and produces CIGS solar cells at record efficiency. Global Solar is the only manufacturer for full-scale production of flexible CIGS solar cells. Sharp Solar is a world leading solar company of Japan and aims to provide reliable solar power from lighthouses to space satellites to mega solar

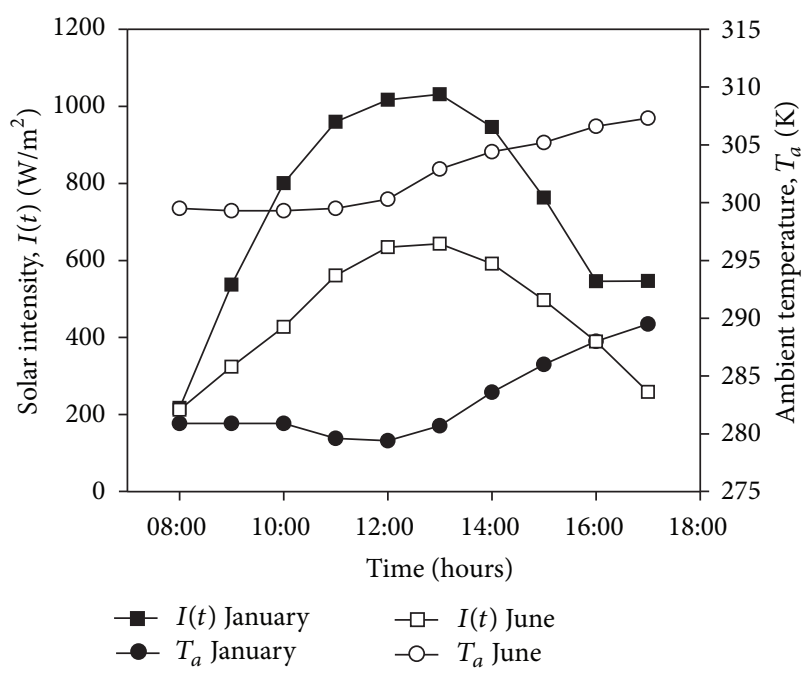

FIGURE 2: Hourly variations of solar intensity $I(t)$ and ambient temperature $\left(T_{a}\right)$ for the months of January and June.

power plants. Sharp Solar has developed world's highest power conversion efficiency of $44.4 \%$ using a concentrator triple junction solar cell. Sharp has also established its own standards for accelerated tests and endurance tests, which are more demanding than the standards set by IEC and JIS international industrial standards.

\section{Results and Discussion}

To solve the mathematical equations, a computer program Mathcad 8 has been used. The calculated hourly variations of $I(t)$ at $30^{\circ}$ inclination and $T_{a}$ for typical clear days of January 


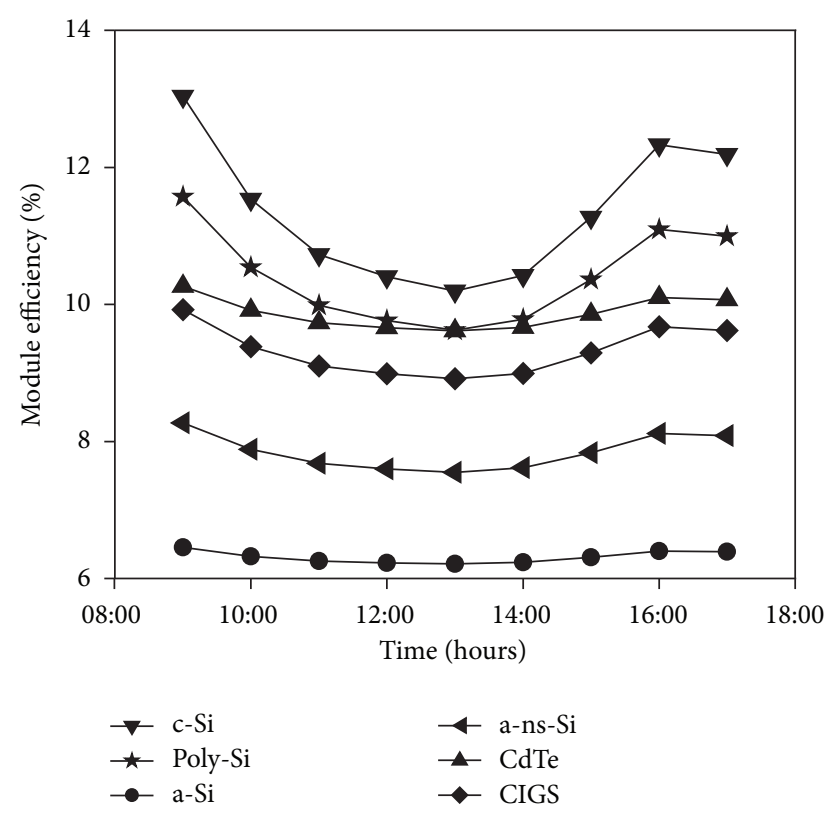

Figure 3: Hourly variations of electrical efficiencies for different commercially available PV modules in the month of January.

and June are shown in Figure 2. As expected, the solar intensity is maximum at $\sim 13: 00$ hrs where the intensity in January is greater than that in June. It is important to note that the solar intensity at any surface depends on its declination angle and the solar altitude. The smaller the angle of inclination of the radiation with horizontal surface, the greater will be the path to travel and the lower radiation reaching the surface. The altitude is more in summer compared to that in winter. The altitude is more in summer compared to that in winter for a given inclination of PV module $\left(\beta=30^{\circ}\right)$. It is also observed that the angle of incidence in January is less than that is June, leading to higher intensity in January. The higher intensity in January due to small angle of incidence $\left(\theta_{i}\right)$ compared to that in June due to large value of angle of incidence $\left(\theta_{i}\right)$ can be understood from the fact that a south facing surface receives higher amount of radiation during winter than during the summer ( $\sim 1.5$ times) for a given inclination $\beta$. As expected, the ambient temperature in January is smaller than that in the June. Figure 3 shows the variation in module efficiency of commercially available different PV modules with time. The calculations have also been done for PV modules which have been considered to be prepared in the laboratory, with STC cell efficiencies (figure not shown). Among the different PV technologies, c-Si PV technology has shown the maximum efficiency for both the modules, commercially available and prepared in laboratory. However, a-Si PV modules have shown the minimum efficiency in both cases. For all the PV technologies, the module efficiencies first decrease and then increase with time. The minimum efficiency for all the PV modules is observed at 13:00 hrs. The variation in module efficiencies can be correlated with the module temperatures shown in Figure 4. Because of different temperature coefficients of different materials, the module temperatures are different. The temperature coefficient of OPV modules has

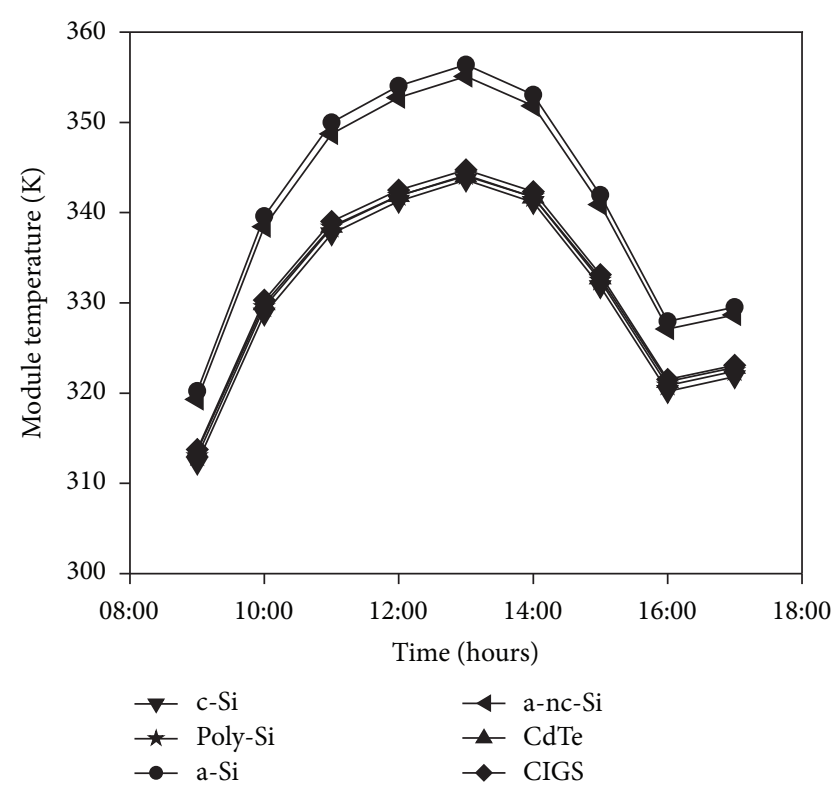

FIGURE 4: Hourly variations of module temperatures for different commercially available PV modules in the month of January.

been calculated using (5), where the desired parameters were obtained from [24]. a-Si has shown the maximum module temperature whereas $\mathrm{c}$-Si exhibited the minimum module temperature. The module temperatures first increase and then decrease with time and are maximum at $\sim 13: 00 \mathrm{hrs}$ which correspond to maximum solar intensity (see Figure 2). Therefore, it can be inferenced that the module efficiencies are minimum for maximum module temperatures, and it is because of the maximum electrical losses due to enhanced collisions of electrons at high temperatures. It is worth mentioning that the electrical resistance in a system is controlled by the electron collisions. For high temperatures the collision will be more that it would result into high resistance, and high resistance would lead to more recombination losses.

Performance evaluation has been carried out for the semitransparent and opaque PV modules, which are commercially available and those prepared in laboratory for the months of January and June. Though all the performance evaluations have been carried out on different PV module technologies, further the results of those prepared with c-Si only are presented, as it is most studied and efficient material. Figure 5 compares the performance of commercially available c-Si semitransparent and opaque PV modules in the months of January and June. In all the cases, the module efficiencies first decrease and then increase with time and are minimum at $\sim$ 13:00 hrs. The reason behind minimum module efficiencies at 13:00 hrs has already been discussed above. It is observed that in both months and semitransparent PV modules have shown the higher efficiencies compared to the opaque ones. The same effect has been observed for all the PV module technologies. Dubey et al. studied the module efficiencies of only c-Si-based semitransparent and opaque modules [11] and observed the similar results. It is important to note that in the case of c-Si and poly c-Si PV modules, the packing factor is considered to be 0.89 . In that case, the solar radiation falling 


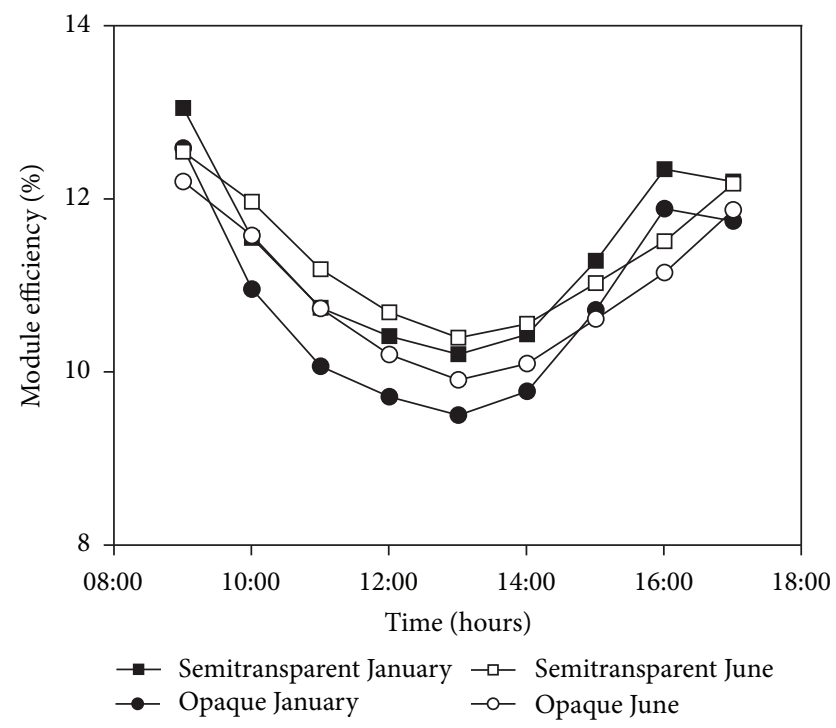

FIGURE 5: Hourly variations of electrical efficiencies of commercially available $\mathrm{c}$-Si semitransparent and opaque PV modules in the months of January and June.

on the nonpacking area is transmitted through the semitransparent module whereas in case of opaque modules it is absorbed by the tedlar sheet. The absorption of solar radiation by tedlar sheet results into the increment in cell temperature, due to which the module efficiency decreases. But in case of thin film PV modules, the packing factor is considered to be 1 and there will be no nonpacking area. However, the higher efficiencies in semitransparent thin film PV modules compared to the opaque ones can be understood from their thin film property. Due to very low thicknesses, some of the heat of the incident radiation is transmitted through the back glass sheet, but in case of opaque modules, it, absorbed by the tedlar sheet. The absorption of solar heat by the tedlar sheet results into increment in the module temperature, due to which the module efficiency decreases. The average module efficiency is observed higher in the month of January than in the month of June. It is because of the reason that in January the ambient temperature is lower compared to that in June. The performance of semitransparent and opaque cSi PV modules, those are commercially available, is compared in Figure 6 with those considered prepared in the laboratory for the month of January. In both cases, the modules prepared in the laboratory have shown higher efficiencies compared to those available in the market. Similar studies have been carried out for different PV module technologies, which have shown the similar behavior. The reason behind this fact is that the cell efficiencies of the modules prepared in the laboratory are higher compared to those prepared on the commercial scale. It is the well-known fact that the efficiencies of the solar cells prepared on the commercial level are always lower than those prepared in the laboratory.

Figure 7 shows the variation of module efficiency as a function of $T_{m}-T_{a} / I(t)$ for commercially available c-Si semitransparent and opaque PV modules in the months of January and June. These characteristics curves are similar to

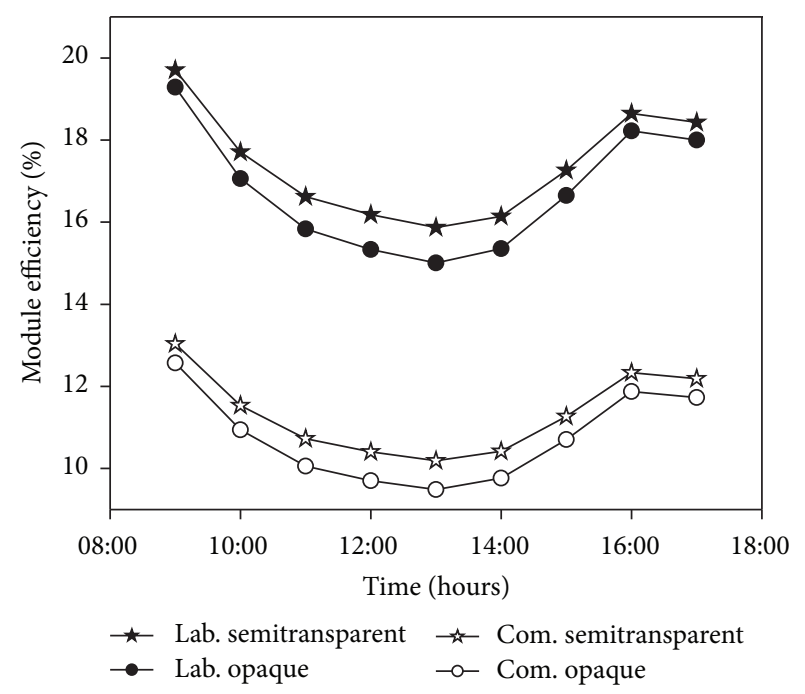

FIGURE 6: Hourly variation of electrical efficiencies of commercially available and laboratory prepared c-Si semitransparent and opaque PV modules in the month of January.

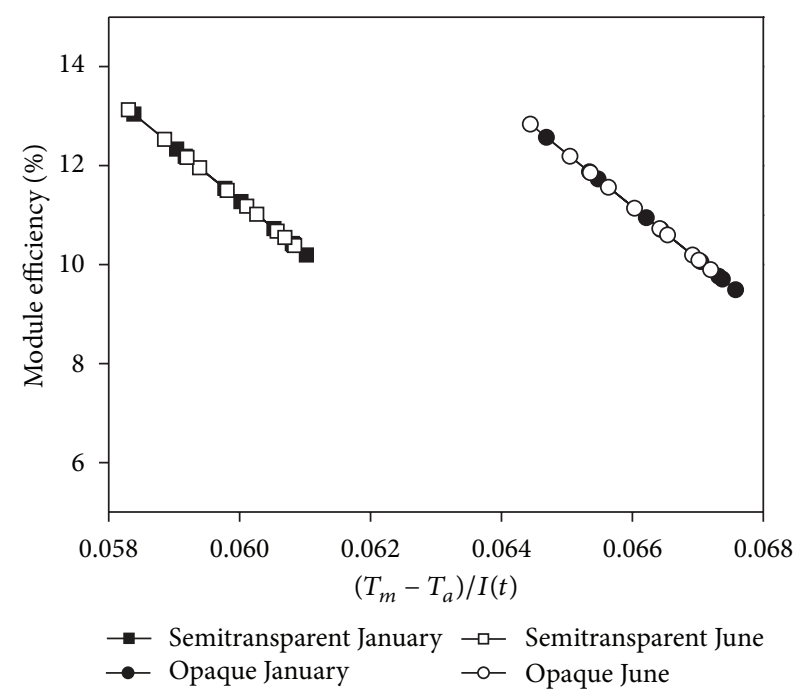

FIGURE 7: Variations of electrical efficiencies of commercially available c-Si semitransparent and opaque PV modules with $T_{m}-$ $T_{a} / I(t)$ in the months of January and June.

the Hottel-Whiller-Bliss equations of a flat plat collector [25]. Both semitransparent and opaque PV modules have shown similar variation in efficiency in the months of January and June; however, their gain factor $(c)$ and loss coefficient $(m)$ are different. All other PV module technologies have also shown the similar behavior but with different loss coefficients and gain factors. The semitransparent PV modules have shown lower modules temperatures compared to the opaque ones irrespective of the testing months of January and June. Similarly, the variation in module efficiencies for opaque and semitransparent c-Si PV modules, those are commercially available and prepared in the laboratory, is shown in Figure 8 as a function of $T_{m}-T_{a} / I(t)$ for the month of January. Though the variation is similar in all cases, their gain factors 
TABLE 3: Loss coefficients $(m)$ and gain factors $(c)$ for different PV modules.

\begin{tabular}{|c|c|c|c|c|c|c|c|c|c|c|}
\hline & & echnology & & $\mathrm{c}-\mathrm{Si}$ & Poly-Si & a-Si & $\mathrm{CdTe}$ & CIGS & a-Si/nc-Si & OPV \\
\hline \multirow{8}{*}{ January } & \multirow{4}{*}{ Lab. } & \multirow{2}{*}{ Semitransparent } & $m$ & 1082.8 & 1072.3 & 1084.6 & 1084.9 & 1079.3 & 1081 & 1075 \\
\hline & & & $c$ & 76.248 & 75.653 & 85.827 & 76.272 & 75.964 & 85.611 & 56.782 \\
\hline & & \multirow{2}{*}{ Opaque } & $m$ & 1067.2 & 1079 & 1057.6 & 1070.9 & 1069.5 & 1070.5 & 1064.4 \\
\hline & & & $c$ & 81.333 & 81.258 & 84.827 & 76.22 & 76.139 & 85.74 & 56.886 \\
\hline & \multirow{4}{*}{ Com. } & \multirow{2}{*}{ Semi-transparent } & $m$ & 1079.1 & 1079.2 & 1092.7 & 1083.3 & 1072.9 & 1076.6 & - \\
\hline & & & $c$ & 76.041 & 76.044 & 86.431 & 76.201 & 75.562 & 85.257 & - \\
\hline & & \multirow{2}{*}{ Opaque } & $m$ & 1067.7 & 1078.5 & 1063.4 & 1064 & 1065.6 & 1064.5 & - \\
\hline & & & $c$ & 81.64 & 81.494 & 84.282 & 75.813 & 75.913 & 85.316 & - \\
\hline \multirow{8}{*}{ June } & \multirow{4}{*}{ Lab. } & \multirow{2}{*}{ Semi-transparent } & $m$ & 1080.4 & 1080.2 & 1086.7 & 1084 & 1080.8 & 1079.8 & 1084.7 \\
\hline & & & $c$ & 76.117 & 76.107 & 85.975 & 76.223 & 76.041 & 85.486 & 57.207 \\
\hline & & \multirow{2}{*}{ Opaque } & $m$ & 1067.9 & 1065.3 & 1089.3 & 1068 & 1065.3 & 1073.8 & 1062.6 \\
\hline & & & $c$ & 81.373 & 81.212 & 86.157 & 76.056 & 75.91 & 85.968 & 56.807 \\
\hline & \multirow{4}{*}{ Com. } & \multirow{2}{*}{ Semi-transparent } & $m$ & 1081.6 & 1079 & 1089.4 & 1079.5 & 1079.6 & 1077.4 & - \\
\hline & & & $c$ & 76.192 & 76.036 & 86.187 & 75.971 & 75.974 & 85.314 & - \\
\hline & & \multirow{2}{*}{ Opaque } & $m$ & 1065.9 & 1066.3 & 1073.2 & 1073.6 & 1065.5 & 1065.7 & - \\
\hline & & & $c$ & 81.524 & 81.549 & 85.962 & 76.413 & 75.905 & 85.407 & - \\
\hline
\end{tabular}

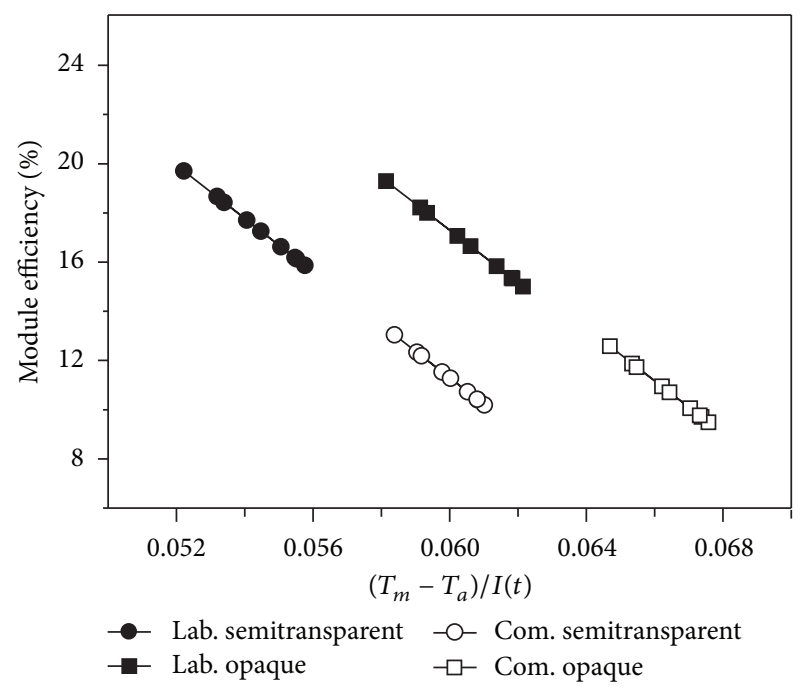

Figure 8: Variations of electrical efficiencies of commercially available and laboratory prepared c-Si semitransparent and opaque PV modules with $T_{m}-T_{a} / I(t)$ in the month of January.

and loss coefficients are different. The laboratory-prepared PV modules have shown lower module temperatures compared to those available commercially, irrespective of their transparency. A similar behavior has been observed for other PV module technologies. The gain factors and loss coefficients for electrical efficiencies of different commercial and laboratory prepared semitransparent and opaque PV modules for the months of January and June have been summarized in Table 3.

Now the cost analysis of different PV modules is presented. Though the different PV modules have different lifetime, the annual electrical energy and cost per unit electrical energy have been calculated for 30 years. The calculations were done for all the materials even considering their degradation. The degradation rates for different PV modules

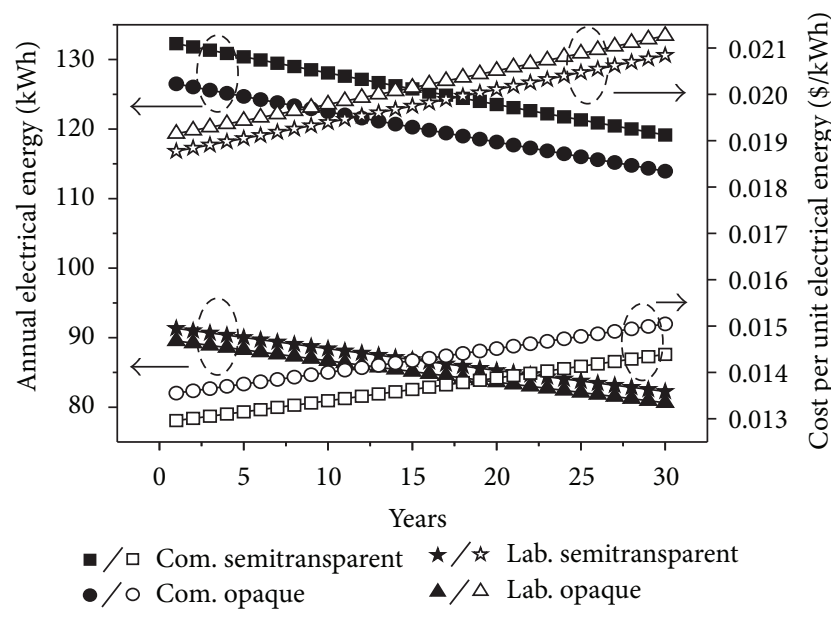

FIGURE 9: Variations in annual electrical energy and cost per unit electrical energy of commercial and laboratory-prepared semitransparent and opaque PV modules of c-Si.

are given in Table 4. The obtained annual electrical energy and cost per unit electrical energy for different commercial semitransparent and opaque PVs are given in Tables 5 and 6 , respectively. Similarly, the annual electrical energy and cost per unit electrical energy for different laboratory prepared PV modules are given in Tables 7 and 8, respectively. The calculations show that for all the PV modules irrespective of their transparency, the annual electrical energy would decrease with time which will result into increment in their corresponding cost per unit electrical energy. Figure 9 shows the variation in annual electrical energy and cost per unit electrical energy of commercial and laboratory prepared c-Si PV modules with time for both semitransparent and opaque structures. Figure 10 compares the initial (maximum) annual electrical energy for different commercial semitransparent and opaque PV modules. For all the PV technologies, semitransparent PV modules have shown higher annual electrical 
TABLE 4: Equivalent present value (Pn), capitalized cost (K), and unacost (R) for different PV modules (75 $\left.W_{p}\right)$.

\begin{tabular}{|c|c|c|c|c|c|c|c|c|}
\hline \multirow{2}{*}{$\begin{array}{l}\text { PV } \\
\text { Technology }\end{array}$} & \multicolumn{3}{|c|}{ Module cost (P1) (\$) } & \multirow[b]{2}{*}{$\begin{array}{l}\text { Lifetime }(n) \\
\quad \text { (years) }\end{array}$} & \multirow[b]{2}{*}{$\begin{array}{l}\text { Degradation } \\
\text { rate }(\% / \text { year })\end{array}$} & \multirow{2}{*}{$\begin{array}{c}\text { Equivalent } \\
\text { present value } \\
\text { Pn }(\$)\end{array}$} & \multirow[b]{2}{*}{$\begin{array}{l}\text { Capitalized } \\
\text { cost }(\mathrm{K})(\$)\end{array}$} & \multirow{2}{*}{$\begin{array}{c}\text { Annualized } \\
\text { uniform cost } \\
\text { (unacost) (R) (\$) }\end{array}$} \\
\hline & $\begin{array}{l}\text { Panel cost } \\
\text { (a) }\end{array}$ & $\begin{array}{l}\text { Stand cost } \\
(b)\end{array}$ & $\begin{array}{l}\text { Total (P1) } \\
(a+b)\end{array}$ & & & & & \\
\hline $\mathrm{c}-\mathrm{Si}$ & 105 & 2.96 & 107.96 & 30 & 0.36 & 241.30 & 21.43 & 1.714 \\
\hline Poly-Si & 90 & 2.78 & 92.78 & 30 & 0.64 & 207.37 & 18.42 & 1.473 \\
\hline $\mathrm{a}-\mathrm{Si}$ & 60 & 3.70 & 63.70 & 20 & 0.87 & 141.27 & 14.39 & 1.151 \\
\hline CdTe & 67.5 & 3.24 & 70.74 & 25 & 0.40 & 157.61 & 14.77 & 1.181 \\
\hline CIGS & 60 & 3.24 & 63.24 & 20 & 0.96 & 140.25 & 14.29 & 1.142 \\
\hline a-Si/nc-Si & 60 & 3.70 & 63.70 & 20 & 0.87 & 141.27 & 14.39 & 1.151 \\
\hline
\end{tabular}

${ }^{*}$ The panel cost has been calculated from the $\$ / \mathrm{Wp}$ values of different modules [26].

TABLE 5: Yearly annual electrical energy (kWh) of different commercial PV modules.

\begin{tabular}{|c|c|c|c|c|c|c|c|c|c|c|c|c|}
\hline \multirow{2}{*}{ Year } & \multicolumn{2}{|c|}{$\mathrm{c}-\mathrm{Si}$} & \multicolumn{2}{|c|}{ Poly-Si } & \multicolumn{2}{|c|}{$\mathrm{a}-\mathrm{Si}$} & \multicolumn{2}{|c|}{$\mathrm{CdTe}$} & \multicolumn{2}{|c|}{ CIGS } & \multicolumn{2}{|c|}{$\mathrm{a}-\mathrm{Si} / \mathrm{nc}-\mathrm{Si}$} \\
\hline & Semi & Opaque & Semi & Opaque & Semi & Opaque & Semi & Opaque & Semi & Opaque & Semi & Opaque \\
\hline 1 & 132.29 & 126.51 & 114.64 & 105.56 & 136.79 & 132.59 & 130.73 & 124.56 & 124.7 & 118.89 & 153.89 & 149 \\
\hline 2 & 131.82 & 126.06 & 113.91 & 104.88 & 135.6 & 131.43 & 130.2 & 124.06 & 123.5 & 117.75 & 152.55 & 147.71 \\
\hline 3 & 131.34 & 125.6 & 113.18 & 104.21 & 134.42 & 130.29 & 129.68 & 123.57 & 122.32 & 116.62 & 151.22 & 146.42 \\
\hline 4 & 130.87 & 125.15 & 112.46 & 103.55 & 133.25 & 129.16 & 129.16 & 123.07 & 121.14 & 115.5 & 149.91 & 145.15 \\
\hline 5 & 130.4 & 124.7 & 111.74 & 102.88 & 132.09 & 128.03 & 128.65 & 122.58 & 119.98 & 114.39 & 148.6 & 143.88 \\
\hline 6 & 129.93 & 124.25 & 111.02 & 102.23 & 130.94 & 126.92 & 128.13 & 122.09 & 118.83 & 113.29 & 147.31 & 142.63 \\
\hline 7 & 129.46 & 123.81 & 110.31 & 101.57 & 129.8 & 125.81 & 127.62 & 121.6 & 117.69 & 112.2 & 146.03 & 141.39 \\
\hline 8 & 128.99 & 123.36 & 109.6 & 100.92 & 128.67 & 124.72 & 127.11 & 121.11 & 116.56 & 111.13 & 144.76 & 140.16 \\
\hline 9 & 128.53 & 122.92 & 108.9 & 100.28 & 127.55 & 123.64 & 126.6 & 120.63 & 115.44 & 110.06 & 143.5 & 138.94 \\
\hline 10 & 128.07 & 122.47 & 108.21 & 99.633 & 126.44 & 122.56 & 126.09 & 120.15 & 114.33 & 109 & 142.25 & 137.73 \\
\hline 11 & 127.61 & 122.03 & 107.51 & 98.996 & 125.34 & 121.49 & 125.59 & 119.67 & 113.23 & 107.96 & 141.01 & 136.54 \\
\hline 12 & 127.15 & 121.59 & 106.82 & 98.362 & 124.25 & 120.44 & 125.09 & 119.19 & 112.15 & 106.92 & 139.79 & 135.35 \\
\hline 13 & 126.69 & 121.15 & 106.14 & 97.732 & 123.17 & 119.39 & 124.59 & 118.71 & 111.07 & 105.89 & 138.57 & 134.17 \\
\hline 14 & 126.23 & 120.72 & 105.46 & 97.107 & 122.1 & 118.35 & 124.09 & 118.24 & 110 & 104.88 & 137.37 & 133 \\
\hline 15 & 125.78 & 120.28 & 104.79 & 96.485 & 121.04 & 117.32 & 123.59 & 117.76 & 108.95 & 103.87 & 136.17 & 131.85 \\
\hline 16 & 125.33 & 119.85 & 104.12 & 95.868 & 119.99 & 116.3 & 123.1 & 117.29 & 107.9 & 102.87 & 134.99 & 130.7 \\
\hline 17 & 124.87 & 119.42 & 103.45 & 95.254 & 118.94 & 115.29 & 122.61 & 116.82 & 106.87 & 101.88 & 133.81 & 129.56 \\
\hline 18 & 124.43 & 118.99 & 102.79 & 94.645 & 117.91 & 114.28 & 122.12 & 116.36 & 105.84 & 100.91 & 132.65 & 128.43 \\
\hline 19 & 123.98 & 118.56 & 102.13 & 94.039 & 116.88 & 113.29 & 121.63 & 115.89 & 104.82 & 99.937 & 131.49 & 127.32 \\
\hline 20 & 123.53 & 118.13 & 101.48 & 93.437 & 115.86 & 112.3 & 121.14 & 115.43 & 103.82 & 98.978 & 130.35 & 126.21 \\
\hline 21 & 123.09 & 117.71 & 100.83 & 92.839 & 114.86 & 111.33 & 120.66 & 114.97 & 102.82 & 98.028 & 129.21 & 125.11 \\
\hline 22 & 122.64 & 117.29 & 100.18 & 92.245 & 113.86 & 110.36 & 120.17 & 114.51 & 101.83 & 97.087 & 128.09 & 124.02 \\
\hline 23 & 122.2 & 116.86 & 99.54 & 91.655 & 112.87 & 109.4 & 119.69 & 114.05 & 100.86 & 96.155 & 126.98 & 122.94 \\
\hline 24 & 121.76 & 116.44 & 98.903 & 91.068 & 111.89 & 108.45 & 119.21 & 113.59 & 99.888 & 95.232 & 125.87 & 121.87 \\
\hline 25 & 121.32 & 116.02 & 98.27 & 90.485 & 110.91 & 107.5 & 118.74 & 113.14 & 98.93 & 94.317 & 124.78 & 120.81 \\
\hline 26 & 120.89 & 115.61 & 97.641 & 89.906 & 109.95 & 106.57 & 118.26 & 112.68 & 97.98 & 93.412 & 123.69 & 119.76 \\
\hline 27 & 120.45 & 115.19 & 97.016 & 89.331 & 108.99 & 105.64 & 117.79 & 112.23 & 97.039 & 92.515 & 122.61 & 118.72 \\
\hline 28 & 120.02 & 114.77 & 96.395 & 88.759 & 108.04 & 104.72 & 117.32 & 111.78 & 96.108 & 91.627 & 121.55 & 117.69 \\
\hline 29 & 119.59 & 114.36 & 95.778 & 88.191 & 107.1 & 103.81 & 116.85 & 111.34 & 95.185 & 90.747 & 120.49 & 116.66 \\
\hline 30 & 119.16 & 113.95 & 95.165 & 87.627 & 106.17 & 102.91 & 116.38 & 110.89 & 94.271 & 89.876 & 119.44 & 115.65 \\
\hline
\end{tabular}

energy compared to the opaque ones. a-Si/nc-Si PV modules have shown the maximum annual electrical energy, whereas poly c-Si PV modules have shown the minimum annual electrical energy. It is found that in case of the PV modules prepared in the laboratory, the maximum annual electrical energy is observed for $\mathrm{CdTe}$, whereas minimum annual electrical energy is observed for a-Si/nc-Si PV modules. After calculation of annual electrical energy, the unit electrical energy was calculated for different PV module technologies. For calculation of unit electrical energy, the annualized uniform cost was calculated using the financial parameters given in Table 4 for interest rate of $8 \%$. The capitalized cost $(K)$ and unacost $(R)$ have also been calculated, and the values are given in Table 4 . The minimum capitalized cost is found 
TABLE 6: Yearly variations of cost per unit electrical energy ( $\$ / \mathrm{kWh})$ of different commercial PV modules.

\begin{tabular}{|c|c|c|c|c|c|c|c|c|c|c|c|c|}
\hline \multirow{2}{*}{ Year } & \multicolumn{2}{|c|}{$\mathrm{c}-\mathrm{Si}$} & \multicolumn{2}{|c|}{ Poly-Si } & \multicolumn{2}{|c|}{$\mathrm{a}-\mathrm{Si}$} & \multicolumn{2}{|c|}{$\mathrm{CdTe}$} & \multicolumn{2}{|c|}{ CIGS } & \multicolumn{2}{|c|}{ a-Si/nc-Si } \\
\hline & Semi & Opaque & Semi & Opaque & Semi & Opaque & Semi & Opaque & Semi & Opaque & Semi & Opaque \\
\hline 1 & 0.013 & 0.0136 & 0.0129 & 0.014 & 0.0084 & 0.0087 & 0.009 & 0.0095 & 0.0092 & 0.0096 & 0.0075 & 0.00773 \\
\hline 2 & 0.013 & 0.0136 & 0.0129 & 0.0141 & 0.0085 & 0.0088 & 0.0091 & 0.0095 & 0.0093 & 0.0097 & 0.0076 & 0.00779 \\
\hline 3 & 0.0131 & 0.0137 & 0.013 & 0.0141 & 0.0086 & 0.0088 & 0.0091 & 0.0096 & 0.0093 & 0.0098 & 0.0076 & 0.00786 \\
\hline 4 & 0.0131 & 0.0137 & 0.0131 & 0.0142 & 0.0086 & 0.0089 & 0.0092 & 0.0096 & 0.0094 & 0.0099 & 0.0077 & 0.00793 \\
\hline 5 & 0.0132 & 0.0138 & 0.0132 & 0.0143 & 0.0087 & 0.009 & 0.0092 & 0.0096 & 0.0095 & 0.01 & 0.0078 & 0.008 \\
\hline 6 & 0.0132 & 0.0138 & 0.0133 & 0.0144 & 0.0088 & 0.0091 & 0.0092 & 0.0097 & 0.0096 & 0.0101 & 0.0078 & 0.00807 \\
\hline 7 & 0.0133 & 0.0139 & 0.0134 & 0.0145 & 0.0089 & 0.0092 & 0.0093 & 0.0097 & 0.0097 & 0.0102 & 0.0079 & 0.00814 \\
\hline 8 & 0.0133 & 0.0139 & 0.0135 & 0.0146 & 0.009 & 0.0092 & 0.0093 & 0.0098 & 0.0098 & 0.0103 & 0.008 & 0.00821 \\
\hline 9 & 0.0133 & 0.014 & 0.0135 & 0.0147 & 0.009 & 0.0093 & 0.0093 & 0.0098 & 0.0099 & 0.0104 & 0.008 & 0.00828 \\
\hline 10 & 0.0134 & 0.014 & 0.0136 & 0.0148 & 0.0091 & 0.0094 & 0.0094 & 0.0098 & 0.01 & 0.0105 & 0.0081 & 0.00836 \\
\hline 11 & 0.0134 & 0.0141 & 0.0137 & 0.0149 & 0.0092 & 0.0095 & 0.0094 & 0.0099 & 0.0101 & 0.0106 & 0.0082 & 0.00843 \\
\hline 12 & 0.0135 & 0.0141 & 0.0138 & 0.015 & 0.0093 & 0.0096 & 0.0094 & 0.0099 & 0.0102 & 0.0107 & 0.0082 & 0.00851 \\
\hline 13 & 0.0135 & 0.0142 & 0.0139 & 0.0151 & 0.0094 & 0.0096 & 0.0095 & 0.01 & 0.0103 & 0.0108 & 0.0083 & 0.00858 \\
\hline 14 & 0.0136 & 0.0142 & 0.014 & 0.0152 & 0.0094 & 0.0097 & 0.0095 & 0.01 & 0.0104 & 0.0109 & 0.0084 & 0.00865 \\
\hline 15 & 0.0136 & 0.0143 & 0.0141 & 0.0153 & 0.0095 & 0.0098 & 0.0096 & 0.01 & 0.0105 & 0.011 & 0.0085 & 0.00873 \\
\hline 16 & 0.0137 & 0.0143 & 0.0142 & 0.0154 & 0.0096 & 0.0099 & 0.0096 & 0.0101 & 0.0106 & 0.0111 & 0.0085 & 0.00881 \\
\hline 17 & 0.0137 & 0.0144 & 0.0142 & 0.0155 & 0.0097 & 0.01 & 0.0096 & 0.0101 & 0.0107 & 0.0112 & 0.0086 & 0.00888 \\
\hline 18 & 0.0138 & 0.0144 & 0.0143 & 0.0156 & 0.0098 & 0.0101 & 0.0097 & 0.0102 & 0.0108 & 0.0113 & 0.0087 & 0.00896 \\
\hline 19 & 0.0138 & 0.0145 & 0.0144 & 0.0157 & 0.0099 & 0.0102 & 0.0097 & 0.0102 & 0.0109 & 0.0114 & 0.0088 & 0.00904 \\
\hline 20 & 0.0139 & 0.0145 & 0.0145 & 0.0158 & 0.0099 & 0.0103 & 0.0098 & 0.0102 & 0.011 & 0.0116 & 0.0088 & 0.00912 \\
\hline 21 & 0.0139 & 0.0146 & 0.0146 & 0.0159 & 0.01 & 0.0103 & 0.0098 & 0.0103 & 0.0111 & 0.0117 & 0.0089 & 0.0092 \\
\hline 22 & 0.014 & 0.0146 & 0.0147 & 0.016 & 0.0101 & 0.0104 & 0.0098 & 0.0103 & 0.0112 & 0.0118 & 0.009 & 0.00928 \\
\hline 23 & 0.014 & 0.0147 & 0.0148 & 0.0161 & 0.0102 & 0.0105 & 0.0099 & 0.0104 & 0.0113 & 0.0119 & 0.0091 & 0.00936 \\
\hline 24 & 0.0141 & 0.0147 & 0.0149 & 0.0162 & 0.0103 & 0.0106 & 0.0099 & 0.0104 & 0.0114 & 0.012 & 0.0092 & 0.00945 \\
\hline 25 & 0.0141 & 0.0148 & 0.015 & 0.0163 & 0.0104 & 0.0107 & 0.01 & 0.0104 & 0.0116 & 0.0121 & 0.0092 & 0.00953 \\
\hline 26 & 0.0142 & 0.0148 & 0.0151 & 0.0164 & 0.0105 & 0.0108 & 0.01 & 0.0105 & 0.0117 & 0.0122 & 0.0093 & 0.00961 \\
\hline 27 & 0.0142 & 0.0149 & 0.0152 & 0.0165 & 0.0106 & 0.0109 & 0.01 & 0.0105 & 0.0118 & 0.0124 & 0.0094 & 0.0097 \\
\hline 28 & 0.0143 & 0.0149 & 0.0153 & 0.0166 & 0.0107 & 0.011 & 0.0101 & 0.0106 & 0.0119 & 0.0125 & 0.0095 & 0.00978 \\
\hline 29 & 0.0143 & 0.015 & 0.0154 & 0.0167 & 0.0108 & 0.0111 & 0.0101 & 0.0106 & 0.012 & 0.0126 & 0.0096 & 0.00987 \\
\hline 30 & 0.0144 & 0.0151 & 0.0155 & 0.0168 & 0.0108 & 0.0112 & 0.0102 & 0.0107 & 0.0121 & 0.0127 & 0.0096 & 0.00995 \\
\hline
\end{tabular}

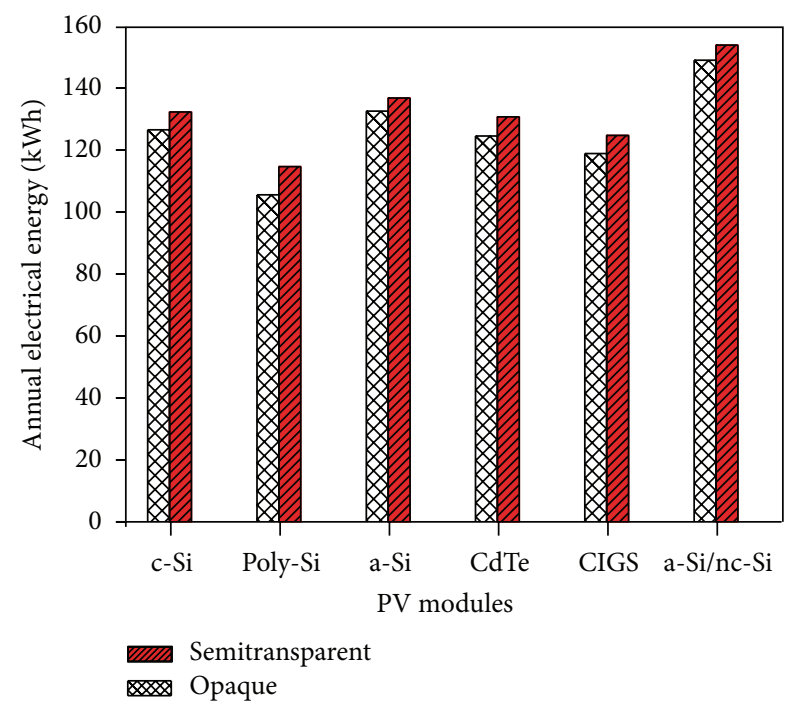

FIGURE 10: Initial (maximum) annual electrical energy for different commercial semitransparent and opaque PV modules. for the CdTe PV modules which means that these are the most economical ones. The initial (maximum) cost per unit electrical energy for different commercial semitransparent and opaque PV module technologies is shown in Figure 11. For all the PV module technologies, the semitransparent PV modules have shown lower unit electrical energy compared to the opaque ones; however, $\mathrm{c}-\mathrm{Si}$ has shown the maximum cost per unit electrical energy whereas minimum cost per unit electrical energy is observed for a-Si/nc-Si PV modules. It is observed that in case of the PV modules prepared in the laboratory, the maximum cost per unit electrical energy is observed for c-Si PV modules whereas the minimum cost per unit electrical energy is observed for CdTe PV modules.

\section{Conclusion}

The outdoor performance of commercially available and laboratory-made different semitransparent and opaque PV modules has been evaluated. The analysis was carried out particularly for the climatic conditions in the months of 
TABLE 7: Yearly annual electrical energy $(\mathrm{kWh})$ of different laboratory- prepared PV modules.

\begin{tabular}{|c|c|c|c|c|c|c|c|c|c|c|c|c|}
\hline \multirow{2}{*}{ Year } & \multicolumn{2}{|c|}{$\mathrm{c}-\mathrm{Si}$} & \multicolumn{2}{|c|}{ Poly-Si } & \multicolumn{2}{|c|}{ a-Si } & \multicolumn{2}{|c|}{$\mathrm{CdTe}$} & \multicolumn{2}{|c|}{ CIGS } & \multicolumn{2}{|c|}{ a-Si/nc-Si } \\
\hline & Semi & Opaque & Semi & Opaque & Semi & Opaque & Semi & Opaque & Semi & Opaque & Semi & Opaque \\
\hline 1 & 91.34 & 89.537 & 93.816 & 92.246 & 90.853 & 90.754 & 102.42 & 102.32 & 96.93 & 96.782 & 90.06 & 89.921 \\
\hline 2 & 91.011 & 89.214 & 93.215 & 91.655 & 90.062 & 89.964 & 102.01 & 101.91 & 96 & 95.853 & 89.276 & 89.139 \\
\hline 3 & 90.684 & 88.893 & 92.619 & 91.069 & 89.279 & 89.181 & 101.6 & 101.5 & 95.078 & 94.933 & 88.499 & 88.363 \\
\hline 4 & 90.357 & 88.573 & 92.026 & 90.486 & 88.502 & 88.405 & 101.2 & 101.1 & 94.166 & 94.021 & 87.729 & 87.594 \\
\hline 5 & 90.032 & 88.254 & 91.437 & 89.907 & 87.732 & 87.636 & 100.79 & 100.69 & 93.262 & 93.119 & 86.966 & 86.832 \\
\hline 6 & 89.708 & 87.936 & 90.852 & 89.332 & 86.969 & 86.874 & 100.39 & 100.29 & 92.366 & 92.225 & 86.21 & 86.077 \\
\hline 7 & 89.385 & 87.62 & 90.27 & 88.76 & 86.212 & 86.118 & 99.985 & 99.888 & 91.48 & 91.339 & 85.46 & 85.328 \\
\hline 8 & 89.063 & 87.304 & 89.693 & 88.192 & 85.462 & 85.369 & 99.585 & 99.488 & 90.601 & 90.462 & 84.716 & 84.586 \\
\hline 9 & 88.742 & 86.99 & 89.119 & 87.627 & 84.719 & 84.626 & 99.187 & 99.09 & 89.732 & 89.594 & 83.979 & 83.85 \\
\hline 10 & 88.423 & 86.677 & 88.548 & 87.066 & 83.981 & 83.89 & 98.79 & 98.694 & 88.87 & 88.734 & 83.248 & 83.12 \\
\hline 11 & 88.105 & 86.365 & 87.982 & 86.509 & 83.251 & 83.16 & 98.395 & 98.299 & 88.017 & 87.882 & 82.524 & 82.397 \\
\hline 12 & 87.787 & 86.054 & 87.418 & 85.956 & 82.527 & 82.437 & 98.001 & 97.906 & 87.172 & 87.038 & 81.806 & 81.68 \\
\hline 13 & 87.471 & 85.744 & 86.859 & 85.405 & 81.809 & 81.719 & 97.609 & 97.514 & 86.335 & 86.203 & 81.094 & 80.97 \\
\hline 14 & 87.156 & 85.436 & 86.303 & 84.859 & 81.097 & 81.008 & 97.219 & 97.124 & 85.506 & 85.375 & 80.389 & 80.265 \\
\hline 15 & 86.843 & 85.128 & 85.751 & 84.316 & 80.391 & 80.304 & 96.83 & 96.736 & 84.686 & 84.556 & 79.69 & 79.567 \\
\hline 16 & 86.53 & 84.821 & 85.202 & 83.776 & 79.692 & 79.605 & 96.443 & 96.349 & 83.873 & 83.744 & 78.996 & 78.875 \\
\hline 17 & 86.218 & 84.516 & 84.657 & 83.24 & 78.999 & 78.912 & 96.057 & 95.963 & 83.067 & 82.94 & 78.309 & 78.188 \\
\hline 18 & 85.908 & 84.212 & 84.115 & 82.707 & 78.311 & 78.226 & 95.673 & 95.58 & 82.27 & 82.144 & 77.628 & 77.508 \\
\hline 19 & 85.599 & 83.909 & 83.576 & 82.178 & 77.63 & 77.545 & 95.29 & 95.197 & 81.48 & 81.355 & 76.952 & 76.834 \\
\hline 20 & 85.291 & 83.607 & 83.042 & 81.652 & 76.955 & 76.871 & 94.909 & 94.817 & 80.698 & 80.574 & 76.283 & 76.165 \\
\hline 21 & 84.984 & 83.306 & 82.51 & 81.129 & 76.285 & 76.202 & 94.529 & 94.437 & 79.923 & 79.801 & 75.619 & 75.503 \\
\hline 22 & 84.678 & 83.006 & 81.982 & 80.61 & 75.621 & 75.539 & 94.151 & 94.06 & 79.156 & 79.035 & 74.961 & 74.846 \\
\hline 23 & 84.373 & 82.707 & 81.457 & 80.094 & 74.964 & 74.882 & 93.774 & 93.683 & 78.396 & 78.276 & 74.309 & 74.195 \\
\hline 24 & 84.069 & 82.409 & 80.936 & 79.582 & 74.311 & 74.23 & 93.399 & 93.309 & 77.643 & 77.524 & 73.663 & 73.549 \\
\hline 25 & 83.766 & 82.113 & 80.418 & 79.072 & 73.665 & 73.584 & 93.026 & 92.935 & 76.898 & 76.78 & 73.022 & 72.909 \\
\hline 26 & 83.465 & 81.817 & 79.903 & 78.566 & 73.024 & 72.944 & 92.654 & 92.564 & 76.16 & 76.043 & 72.387 & 72.275 \\
\hline 27 & 83.164 & 81.522 & 79.392 & 78.063 & 72.389 & 72.31 & 92.283 & 92.193 & 75.429 & 75.313 & 71.757 & 71.646 \\
\hline 28 & 82.865 & 81.229 & 78.884 & 77.564 & 71.759 & 71.681 & 91.914 & 91.825 & 74.705 & 74.59 & 71.132 & 71.023 \\
\hline 29 & 82.567 & 80.936 & 78.379 & 77.067 & 71.135 & 71.057 & 91.546 & 91.457 & 73.987 & 73.874 & 70.514 & 70.405 \\
\hline 30 & 82.269 & 80.645 & 77.877 & 76.574 & 70.516 & 70.439 & 91.18 & 91.091 & 73.277 & 73.165 & 69.9 & 69.792 \\
\hline
\end{tabular}

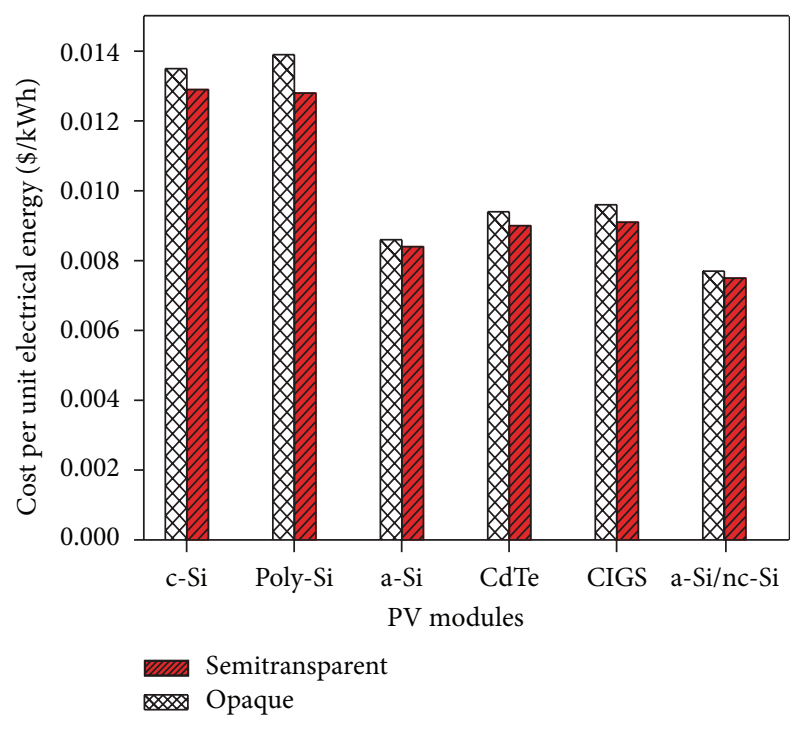

FIGURE 11: Initial (maximum) cost per unit electrical energy for different commercial semitransparent and opaque PV modules.

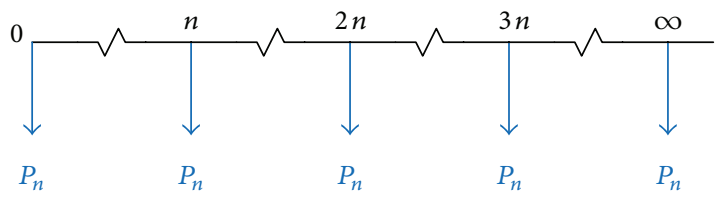

FiguRE 12

January and June in New Delhi, India. On average, the commercial c-Si PV module has shown 1.8 time more efficiency compared to that of a-Si, whereas laboratory-made c-Si PV module has shown 1.9 times more efficiency compared to that of a-Si PV module. For all the PV module technologies, the efficiency first decreases and then increases with time from morning to evening in both months of January and June. This variation in efficiency has been correlated with the module temperature. At high module temperatures, the efficiency is observed to be low. The commercial a-Si PV module has shown $0.8 \%$ more temperature compared to that of c-Si. Nearly, all the PV technologies for both opaque and 
TABLE 8: Yearly variations of cost per unit electrical energy ( $\$ / \mathrm{kWh})$ of different laboratory prepared PV modules.

\begin{tabular}{|c|c|c|c|c|c|c|c|c|c|c|c|c|}
\hline \multirow{2}{*}{ Year } & \multicolumn{2}{|c|}{$\mathrm{c}-\mathrm{Si}$} & \multicolumn{2}{|c|}{ Poly-Si } & \multicolumn{2}{|c|}{$\mathrm{a}-\mathrm{Si}$} & \multicolumn{2}{|c|}{$\mathrm{CdTe}$} & \multicolumn{2}{|c|}{ CIGS } & \multicolumn{2}{|c|}{ a-Si/nc-Si } \\
\hline & Semi & Opaque & Semi & Opaque & Semi & Opaque & Semi & Opaque & Semi & Opaque & Semi & Opaque \\
\hline 1 & 0.0188 & 0.0192 & 0.0157 & 0.016 & 0.0127 & 0.0127 & 0.0115 & 0.0115 & 0.0118 & 0.0118 & 0.0128 & 0.0128 \\
\hline 2 & 0.0188 & 0.0192 & 0.0158 & 0.0161 & 0.0128 & 0.0128 & 0.0116 & 0.0116 & 0.0119 & 0.0119 & 0.0129 & 0.0129 \\
\hline 3 & 0.0189 & 0.0193 & 0.0159 & 0.0162 & 0.0129 & 0.0129 & 0.0116 & 0.0116 & 0.012 & 0.012 & 0.013 & 0.013 \\
\hline 4 & 0.019 & 0.0194 & 0.016 & 0.0163 & 0.013 & 0.013 & 0.0117 & 0.0117 & 0.0121 & 0.0122 & 0.0131 & 0.0131 \\
\hline 5 & 0.0191 & 0.0194 & 0.0161 & 0.0164 & 0.0131 & 0.0131 & 0.0117 & 0.0117 & 0.0123 & 0.0123 & 0.0132 & 0.0133 \\
\hline 6 & 0.0191 & 0.0195 & 0.0162 & 0.0165 & 0.0132 & 0.0133 & 0.0118 & 0.0118 & 0.0124 & 0.0124 & 0.0134 & 0.0134 \\
\hline 7 & 0.0192 & 0.0196 & 0.0163 & 0.0166 & 0.0134 & 0.0134 & 0.0118 & 0.0118 & 0.0125 & 0.0125 & 0.0135 & 0.0135 \\
\hline 8 & 0.0193 & 0.0196 & 0.0164 & 0.0167 & 0.0135 & 0.0135 & 0.0119 & 0.0119 & 0.0126 & 0.0126 & 0.0136 & 0.0136 \\
\hline 9 & 0.0193 & 0.0197 & 0.0165 & 0.0168 & 0.0136 & 0.0136 & 0.0119 & 0.0119 & 0.0127 & 0.0128 & 0.0137 & 0.0137 \\
\hline 10 & 0.0194 & 0.0198 & 0.0166 & 0.0169 & 0.0137 & 0.0137 & 0.012 & 0.012 & 0.0129 & 0.0129 & 0.0138 & 0.0139 \\
\hline 11 & 0.0195 & 0.0199 & 0.0168 & 0.017 & 0.0138 & 0.0138 & 0.012 & 0.012 & 0.013 & 0.013 & 0.014 & 0.014 \\
\hline 12 & 0.0195 & 0.0199 & 0.0169 & 0.0171 & 0.014 & 0.014 & 0.0121 & 0.0121 & 0.0131 & 0.0131 & 0.0141 & 0.0141 \\
\hline 13 & 0.0196 & 0.02 & 0.017 & 0.0173 & 0.0141 & 0.0141 & 0.0121 & 0.0121 & 0.0132 & 0.0133 & 0.0142 & 0.0142 \\
\hline 14 & 0.0197 & 0.0201 & 0.0171 & 0.0174 & 0.0142 & 0.0142 & 0.0122 & 0.0122 & 0.0134 & 0.0134 & 0.0143 & 0.0143 \\
\hline 15 & 0.0198 & 0.0201 & 0.0172 & 0.0175 & 0.0143 & 0.0143 & 0.0122 & 0.0122 & 0.0135 & 0.0135 & 0.0145 & 0.0145 \\
\hline 16 & 0.0198 & 0.0202 & 0.0173 & 0.0176 & 0.0144 & 0.0145 & 0.0123 & 0.0123 & 0.0136 & 0.0137 & 0.0146 & 0.0146 \\
\hline 17 & 0.0199 & 0.0203 & 0.0174 & 0.0177 & 0.0146 & 0.0146 & 0.0123 & 0.0123 & 0.0138 & 0.0138 & 0.0147 & 0.0147 \\
\hline 18 & 0.02 & 0.0204 & 0.0175 & 0.0178 & 0.0147 & 0.0147 & 0.0124 & 0.0124 & 0.0139 & 0.0139 & 0.0148 & 0.0149 \\
\hline 19 & 0.02 & 0.0204 & 0.0176 & 0.0179 & 0.0148 & 0.0148 & 0.0124 & 0.0124 & 0.014 & 0.0141 & 0.015 & 0.015 \\
\hline 20 & 0.0201 & 0.0205 & 0.0178 & 0.0181 & 0.015 & 0.015 & 0.0125 & 0.0125 & 0.0142 & 0.0142 & 0.0151 & 0.0151 \\
\hline 21 & 0.0202 & 0.0206 & 0.0179 & 0.0182 & 0.0151 & 0.0151 & 0.0125 & 0.0125 & 0.0143 & 0.0143 & 0.0152 & 0.0153 \\
\hline 22 & 0.0203 & 0.0207 & 0.018 & 0.0183 & 0.0152 & 0.0152 & 0.0126 & 0.0126 & 0.0144 & 0.0145 & 0.0154 & 0.0154 \\
\hline 23 & 0.0203 & 0.0207 & 0.0181 & 0.0184 & 0.0154 & 0.0154 & 0.0126 & 0.0126 & 0.0146 & 0.0146 & 0.0155 & 0.0155 \\
\hline 24 & 0.0204 & 0.0208 & 0.0182 & 0.0185 & 0.0155 & 0.0155 & 0.0127 & 0.0127 & 0.0147 & 0.0147 & 0.0156 & 0.0157 \\
\hline 25 & 0.0205 & 0.0209 & 0.0183 & 0.0186 & 0.0156 & 0.0156 & 0.0127 & 0.0127 & 0.0149 & 0.0149 & 0.0158 & 0.0158 \\
\hline 26 & 0.0205 & 0.021 & 0.0184 & 0.0188 & 0.0158 & 0.0158 & 0.0128 & 0.0128 & 0.015 & 0.015 & 0.0159 & 0.0159 \\
\hline 27 & 0.0206 & 0.021 & 0.0186 & 0.0189 & 0.0159 & 0.0159 & 0.0128 & 0.0128 & 0.0152 & 0.0152 & 0.016 & 0.0161 \\
\hline 28 & 0.0207 & 0.0211 & 0.0187 & 0.019 & 0.016 & 0.0161 & 0.0129 & 0.0129 & 0.0153 & 0.0153 & 0.0162 & 0.0162 \\
\hline 29 & 0.0208 & 0.0212 & 0.0188 & 0.0191 & 0.0162 & 0.0162 & 0.0129 & 0.0129 & 0.0155 & 0.0155 & 0.0163 & 0.0164 \\
\hline 30 & 0.0208 & 0.0213 & 0.0189 & 0.0192 & 0.0163 & 0.0163 & 0.013 & 0.013 & 0.0156 & 0.0156 & 0.0165 & 0.0165 \\
\hline
\end{tabular}

semitransparent modules have shown similar behavior, but semitransparent modules exhibited higher efficiencies $(\sim 1.04$ times) compared to the opaque ones. However, the module efficiency in January is $\sim 1.02$ time more than that in June. Laboratory made PV modules have shown $\sim 1.5$ times higher efficiencies compared to those available in the market. For laboratory made PV modules, CdTe has shown the maximum annual electrical energy, whereas among the commercial PV modules, a-Si/nc-Si has shown maximum annual electrical energy generation. In case of laboratory PV modules, a$\mathrm{Si} / \mathrm{nc}-\mathrm{Si}$ has the minimum annual electric energy generation, whereas in case of commercial PV modules, poly-Si gas shown the minimum annual electric energy generation. For the PV modules made in the laboratory, $\mathrm{c}-\mathrm{Si}$ has shown the maximum cost per unit electrical energy, whereas among the commercial PV modules, poly-Si has shown the maximum cost per unit electrical energy. For laboratory made PV modules, CdTe has shown the minimum cost per unit electrical energy, whereas among the commercial PV modules, the
a-Si/nc-Si has shown the minimum cost for unit electrical energy. The capitalized cost is found to be minimum for CIGS PV modules.

\section{Nomenclature}

$A_{m}$ : Area of module $\left(\mathrm{m}^{2}\right)$

$h_{0}$ : Heat loss coefficient from the top $\left(\mathrm{W} / \mathrm{m}^{2}\right)$

$h_{i}$ : Heat loss coefficient from the bottom $\left(\mathrm{W} / \mathrm{m}^{2}\right)$

$I(t)$ : Incident solar intensity $\left(\mathrm{W} / \mathrm{m}^{2}\right)$

$K$ : Thermal conductivity $(\mathrm{W} / \mathrm{m} \mathrm{K})$

$T: \quad$ Temperature (K)

$U_{T}$ : Overall top loss heat transfer coefficient from solar cell to ambient $\left(\mathrm{W} / \mathrm{m}^{2} \mathrm{~K}\right)$

$U_{b}$ : Overall bottom loss heat transfer coefficient from solar cell to ambient $\left(\mathrm{W} / \mathrm{m}^{2} \mathrm{~K}\right)$

L: $\quad$ Length (m) 
$R$ : Reflectivity

$v$ : Air velocity.

\section{Subscripts \\ a: Ambient \\ c: Solar cell \\ g: Glass \\ m: Module \\ T: Tedlar \\ E: EVA.}

\section{Greek letters}

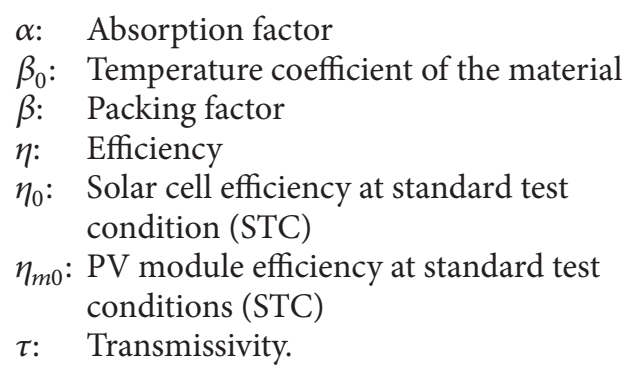

\section{Acknowledgment}

One of the authors (Ankita Gaur) is thankful to the Department of Science and Technology, New Delhi, India, for providing INSPIRE fellowship to pursue the present research work.

\section{References}

[1] D. M. Chapin, C. S. Fuller, and G. L. Pearson, "A new silicon p-n junction photocell for converting solar radiation into electrical power," Journal of Applied Physics, vol. 25, no. 5, pp. 676-677, 1954.

[2] http://www.nrel.gov.

[3] M. A. Green, K. Emery, Y. Hishikawa, W. Warta, and E. D. Dunlop, "Solar cell efficiency tables (version 41)," Progress in Photovoltaics, vol. 21, pp. 1-11, 2013.

[4] K. Vats and G. N. Tiwari, "Energy and exergy analysis of a building integrated semitransparent photovoltaic thermal (BISPVT) system," Applied Energy, vol. 96, pp. 409-416, 2012.

[5] K. Vats, V. Tomar, and G. N. Tiwari, "Effect of packing factor on the performance of a building integrated semitransparent photovoltaic thermal (BISPVT) system with air duct," Energy and Buildings, vol. 53, pp. 159-165, 2012.

[6] C. L. Cheng, C. S. Sanchez Jimenez, and M.-C. Lee, "Research of BIPV optimal tilted angle, use of latitude concept for south orientated plans," Renewable Energy, vol. 34, no. 6, pp. 16441650, 2009.

[7] G. N. Tiwari, Solar Energy: Fundamentals, Design, Modeling and Applications, Narosa Publishing House, 2004.

[8] J. Duffie and W. Beckman, Solar Engineering of Thermal Processes, Wiley, New York, NY, USA, 1974.

[9] B. Agrawal and G. N. Tiwari, "Optimizing the energy and exergy of building integrated photovoltaic thermal (BIPVT) systems under cold climatic conditions," Applied Energy, vol. 87, no. 2, pp. 417-426, 2010.
[10] G. N. Tiwari and R. K. Mishra, Advanced Renewable Energy Sources, CB4 0WF, RSC Publishing Thomas Grahman House, Cambridge, UK, 2012.

[11] S. Dubey, G. S. Sandhu, and G. N. Tiwari, "Analytical expression for electrical efficiency of PV/T hybrid air collector," Applied Energy, vol. 86, no. 5, pp. 697-705, 2009.

[12] E. Skoplaki and J. A. Palyvos, "On the temperature dependence of photovoltaic module electrical performance: a review of efficiency/power correlations," Solar Energy, vol. 83, no. 5, pp. 614-624, 2009.

[13] D. L. Evans, "Simplified method for predicting photovoltaic array output," Solar Energy, vol. 27, no. 6, pp. 555-560, 1981.

[14] B. Y. H. Liu and R. C. Jordan, "The interrelationship and characteristic distribution of direct, diffuse and total solar radiation," Solar Energy, vol. 4, no. 3, pp. 1-19, 1960.

[15] W. Durisch, B. Bitnar, J.-C. Mayor, H. Kiess, K.-H. Lam, and J. Close, "Efficiency model for photovoltaic modules and demonstration of its application to energy yield estimation," Solar Energy Materials and Solar Cells, vol. 91, no. 1, pp. 79-84, 2007.

[16] S. Nann and K. Emery, "Spectral effects on PV-device rating," Solar Energy Materials and Solar Cells, vol. 27, no. 3, pp. 189216, 1992.

[17] T. Yamawaki, S. Mizukami, T. Masui, and H. Takahashi, "Experimental investigation on generated power of amorphous PV module for roof azimuth," Solar Energy Materials and Solar Cells, vol. 67, no. 1-4, pp. 369-377, 2001.

[18] Sanyo Solar Ark, http://www.sanyo.com.

[19] Uni-Solar (United Solar System Corp), http://www.unisolar .com.

[20] First Solar, http://www.firstsolar.com.

[21] Global Solar Energy, http://www.globalsolar.com.

[22] Sharp Solar, http://www.sharp-solar.com.

[23] D. C. Jordan and S. R. Kurtz, NREL/JA-5200-51664 June, 2012.

[24] I. Riedel, J. Parisi, V. Dyakonov, L. Lutsen, D. Vanderzande, and J. C. Hummelen, "Effect of temperature and illumination on the electrical characteristics of polymer-fullerene bulkheterojunction solar cells," Advanced Functional Materials, vol. 14, no. 1, pp. 38-44, 2004.

[25] H. C. Hottel and A. Whillier, "Evaluation of flate plate collector performance," in Proceedings of the Transactions of the Conference on the Use of Solar Energy, vol. 2, p. 74, University of Arizona Press, 1958.

[26] International Renewable energy Agency (IRENA), Solar Photovoltaics, 2012, 1, 4/5. 


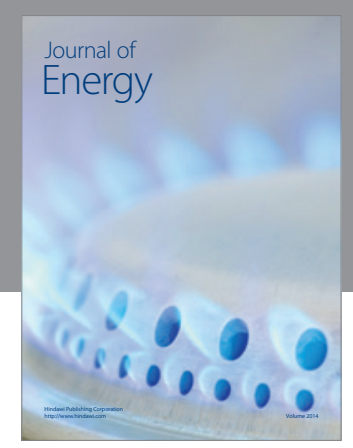

Journal of

Industrial Engineering
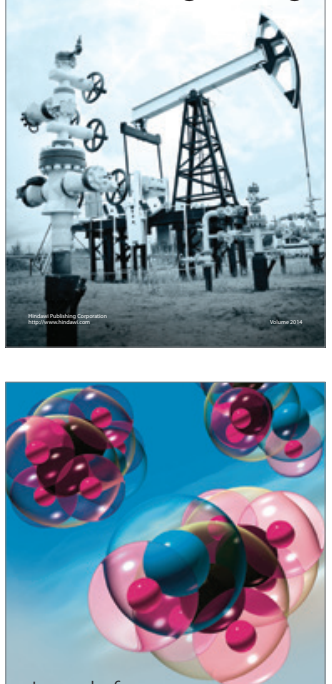

Fuels
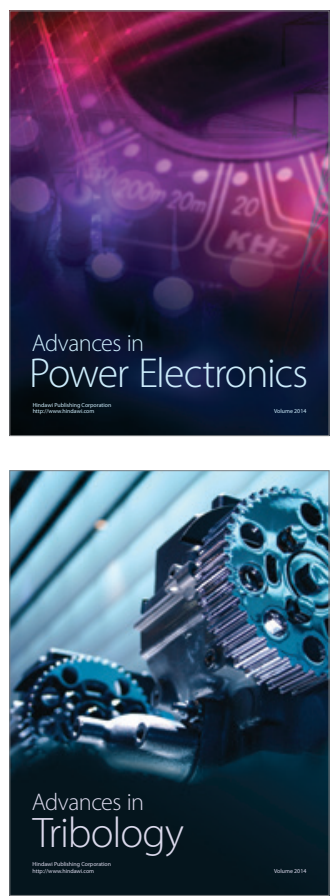

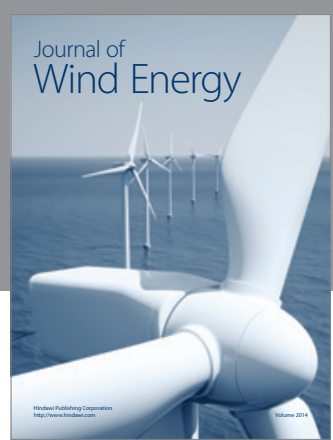

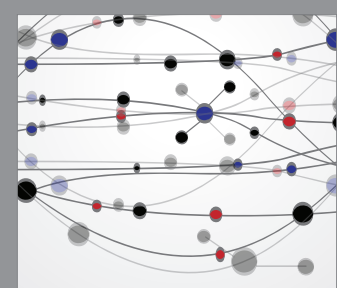

The Scientific World Journal

Submit your manuscripts at http://www.hindawi.com

Journal of

Structures
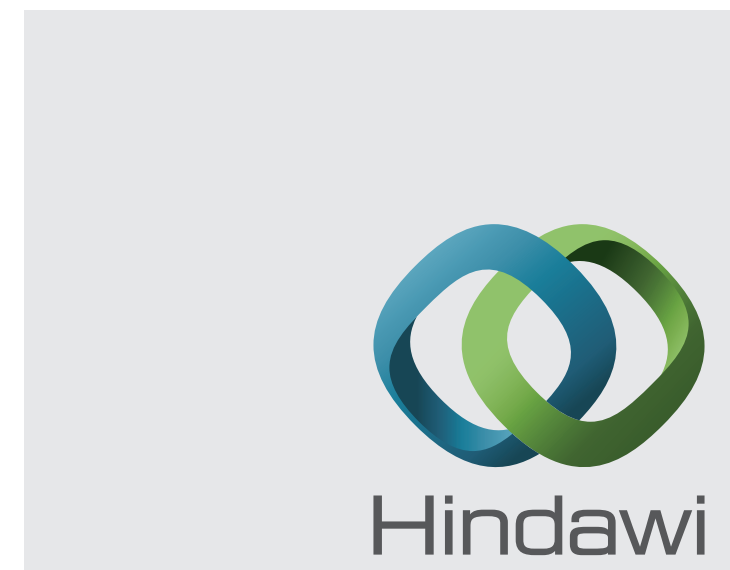

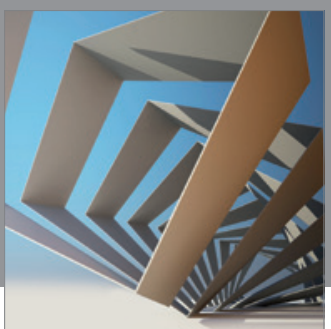

Rotating

Machinery
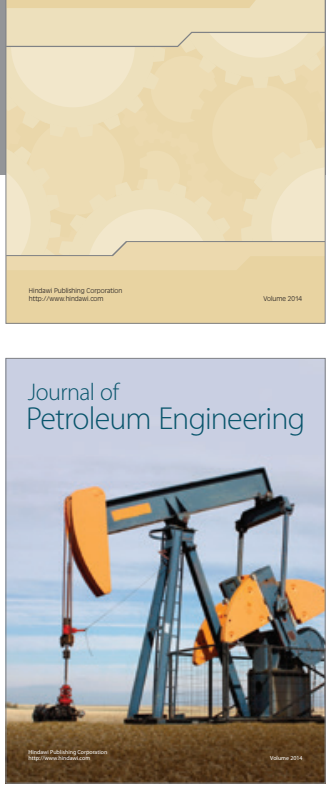

Journal of

Solar Energy
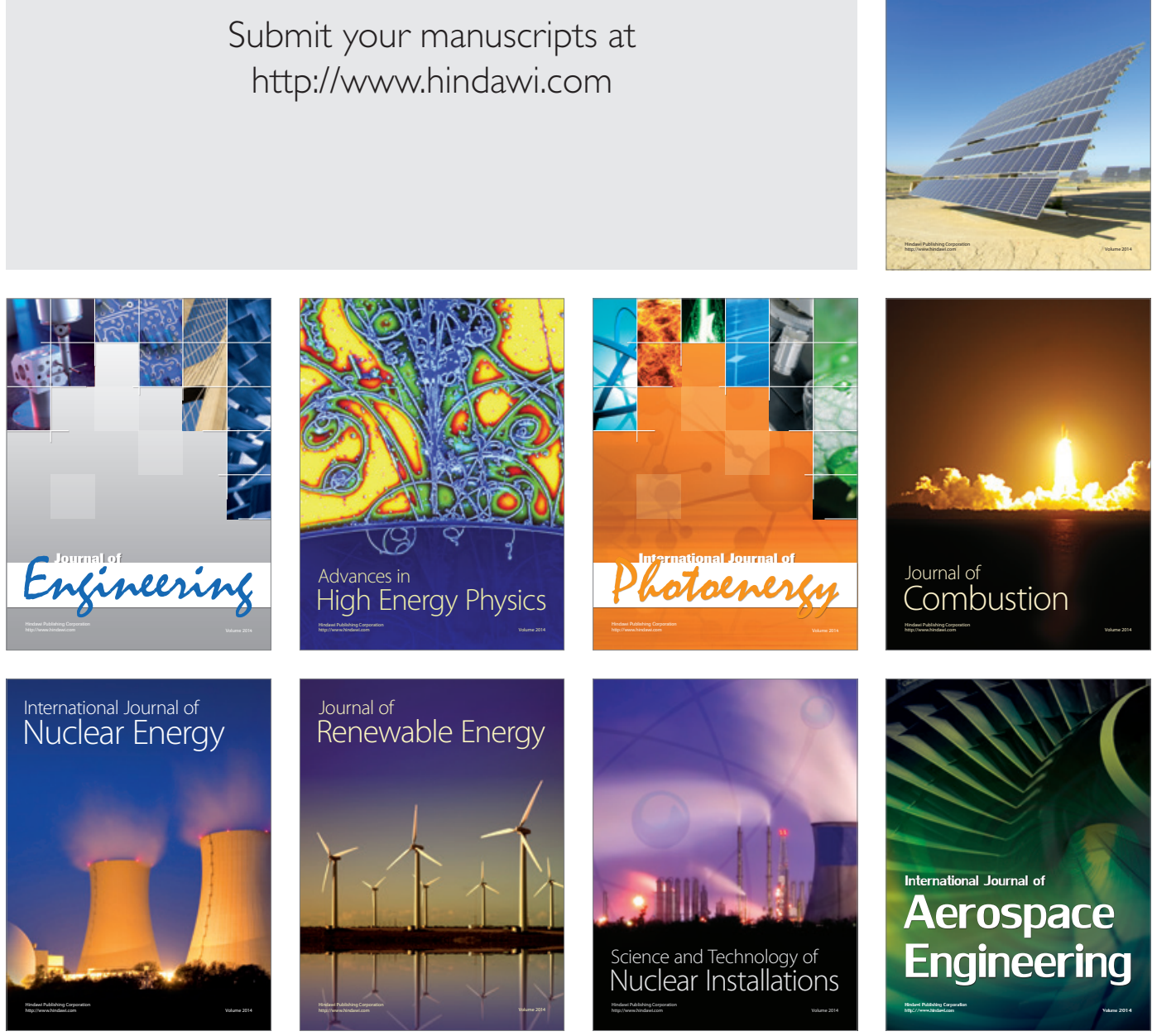